Gadjah Mada International Journal of Business

May-August 2007, Vol. 9, No. 2, pp. 217-251

\title{
THE RESPONSE OF CORPORATE DIVIDEND POLICY TO THE ABOLITION OF TAX CREDIT IN THE UNITED KINGDOM (U.K.)
}

\author{
Hardo Basuki
}

Byabolishing the tax credit on dividends received by tax-exempt financial institutions in 1997, the effective rate of tax for shareholders such as pension funds increases significantly, and the tax preference for dividends is significantly reduced. The tax-exempt shareholders mainly consist of pension funds and insurance companies with respect to their pension business. This tax-exempt community is the most influential shareholders in many U.K. companies, and their tax preference for dividends may have an important impact on corporate dividend policy.

The objective of this study is to examine whether the aggregate dividend payment changes following the 1997 abolition of the tax credit. Using aggregate data in time series from 1974 to 1999, this study finds that the percentage of forecast error in Lintner's model does not change significantly between the pre-and post-abolition periods. Hence, there is no evidence that aggregate dividend payment decreases following the abolition of tax credit. This could be interpreted that the aggregate sample of U.K. firms indicates a little intention of changing their dividend policies in response to the abolition of tax credit.

This study also investigates whether individual U.K. companies respond to the 1997 abolition of tax-credit. The test results show that the majority of companies in the sample do not change their dividend policies after the abolition of tax credit. It is possible that companies are reluctant to cut their dividend payment since the existing dividend payout could be sustained in the long-run. They also avoid sending negative signals to the market. Thus, companies typically chose to keep a dividend level relatively stable following the tax change in 1997. Only the minority of the U.K. companies experience 
Gadjah Mada International Journal of Business, May - August 2007, Vol. 9, No. 2

a decline in their dividend payment. This evidence supports the hypothesis that the abolition of tax credit on dividends results in a decrease in aggregate dividend payment in order to satisfy a tax clientele.

Keywords: abolition of tax credit; aggregate dividend payment; dividend policy

\section{Introduction}

Since 1973, the U.K. government has operated an imputation tax system under which some tax relief on dividend income is provided to all stockholders in recognition of corporation tax paid by a company. The corporation tax is payable in two installments. The first payment (Advance Corporation Tax) is carried out soon after the company pays its dividends, and is assessed on the amount of the dividends. The rate of Advance Corporation $\operatorname{Tax}(\mathrm{ACT})$ is set equal to the lower band rate of income tax on dividend from 1994 (previously the basic rate). For instance, in 1998, the U.K. companies were taxed at a rate of 30 percent on their taxable profits (see Table 1). The ACT was paid at a rate of 20 percent on the gross dividends received by a shareholder.

The second payment of corporate tax (Mainstream Corporation Tax) is payable approximately 9 months after the end of the firm's accounting period. The company can subtract the ACT (the first payment) from its total corporation tax liability, and pay the difference between the total tax bill and ACT already paid. In 1988, the U.K. government abolished all rates of income tax above 40 percent, thereby reducing the top rate from 60 percent to 40 percent. The basic rate of income tax was cut from 30 percent to 29 percent in 1986, then to 27 percent in 1987, and to 25 percent in 1988. In 1993, the Conservative government cut the tax credit (ACT) from 25 percent to 20 percent. In 1997, the Labor government proposed to reduce the tax credit rate from 20 percent to 10 percent starting in 1999. The government also reduced the top corporate tax rate to 31 percent in 1997.

Table 2 shows the comparison of dividend income received by shareholders under the imputation tax system and that received under the classical tax system. Suppose a company has $£ 1,000$ of pre-tax profits distributed as dividends. Under the classical system, the company will pay out $£ 1,000$ (1-tc) to the shareholders, and the shareholders will actually receive the dividend income after tax as much as $£ 1,000(1-\mathrm{tc})(1-\mathrm{m})$, where tc $=$ corporate tax and $\mathrm{m}=$ dividend income tax. For instance, in 1996, if the corporation tax was equal to 33 percent, taxexempt shareholders (pension funds) would receive dividend income after tax of $£ 670$ [ $=£ 1,000(1-0.33)(1-0 \%)]$. If the corporation tax decreased by 2 percent in 1997 (tc=31\%), the dividend income after tax received by tax- 
Basuki-The Response of Corporate Dividend Policy to The Abolition of Tax ...

Table 1. UK Corporate Tax Rate, Dividend Income Tax Rate and Tax Credit Rate (1987-1999)

\begin{tabular}{|c|c|c|c|c|c|}
\hline \multirow[t]{2}{*}{ Year } & \multirow{2}{*}{$\begin{array}{c}\text { Corporate } \\
\text { Tax Rate } \\
\text { (tc) }\end{array}$} & \multicolumn{3}{|c|}{ Dividend Income Tax Rate (m) } & \multirow{2}{*}{$\begin{array}{c}\text { Tax Credi } \\
\text { Rate } \\
\text { (s) }\end{array}$} \\
\hline & & $\begin{array}{l}\text { Lower Rate } \\
\text { (Basic Rate) }\end{array}$ & Top Rate & Exempt & \\
\hline 1987 & $35 \%$ & $27 \%$ & $60 \%$ & $0 \%$ & $27 \%$ \\
\hline 1988 & $35 \%$ & $25 \%$ & $40 \%$ & $0 \%$ & $25 \%$ \\
\hline 1989 & $35 \%$ & $25 \%$ & $40 \%$ & $0 \%$ & $25 \%$ \\
\hline 1990 & $35 \%$ & $25 \%$ & $40 \%$ & $0 \%$ & $25 \%$ \\
\hline 1991 & $33 \%$ & $25 \%$ & $40 \%$ & $0 \%$ & $25 \%$ \\
\hline 1992 & $33 \%$ & $25 \%$ & $40 \%$ & $0 \%$ & $25 \%$ \\
\hline 1993 & $33 \%$ & $25 \%$ & $40 \%$ & $0 \%$ & $25 \%$ \\
\hline 1994 & $33 \%$ & $20 \%$ & $40 \%$ & $0 \%$ & $20 \%$ \\
\hline 1995 & $33 \%$ & $20 \%$ & $40 \%$ & $0 \%$ & $20 \%$ \\
\hline 1996 & $33 \%$ & $20 \%$ & $40 \%$ & $0 \%$ & $20 \%$ \\
\hline 1997 & $31 \%$ & $20 \%$ & $40 \%$ & $0 \%$ & $20 \%$ \\
\hline 1998 & $31 \%$ & $20 \%$ & $40 \%$ & $0 \%$ & $20 \%$ \\
\hline 1999 & $30 \%$ & $10 \%$ & $33 \%$ & $0 \%$ & $10 \%$ \\
\hline
\end{tabular}

* The rate of ACT was set equal to lower band rate from 1994 (previously basic rate).

Table 2. Comparison of Dividend Income under the Imputation Tax System and the Classical Tax System

\begin{tabular}{|c|c|c|c|c|c|c|c|}
\hline \multicolumn{4}{|c|}{$\begin{array}{c}\text { Dividend Income Received } \\
\text { By Shareholders } \\
\text { Under the IMPUTATION SYSTEM } \\
(\mathbf{s = 2 0 \% )} \\
£ 100 *(1-\mathrm{tc})^{*}(1-\mathrm{m}) /(1-\mathrm{s})\end{array}$} & \multicolumn{4}{|c|}{$\begin{array}{c}\text { Dividend Income Received } \\
\text { By Shareholders } \\
\text { Under the CLASSICAL SYSTEM } \\
£ 100^{*}(1-\mathrm{tc})^{*}(1-\mathrm{m})\end{array}$} \\
\hline Year & $\begin{array}{c}\text { Basic Rate } \\
\mathbf{m}=\mathbf{2 0} \%\end{array}$ & $\begin{array}{c}\text { Top Rate } \\
\mathbf{m}=40 \%\end{array}$ & $\begin{array}{c}\text { Exempt } \\
m=0 \%\end{array}$ & Year & $\begin{array}{c}\text { Basic Rate } \\
\mathbf{m}=\mathbf{2 0} \%\end{array}$ & $\begin{array}{c}\text { Top Rate } \\
\mathrm{m}=\mathbf{4 0 \%}\end{array}$ & $\begin{array}{l}\text { Exempt } \\
\text { m=0\% }\end{array}$ \\
\hline $\begin{array}{c}1996 \\
(\mathrm{tc}=33 \%)\end{array}$ & $£ 670.0$ & $£ 502.5$ & $£ 837.5$ & $\begin{array}{c}1996 \\
(\mathrm{tc}=33 \%)\end{array}$ & $£ 536.0$ & $£ 402.0$ & $£ 670.0$ \\
\hline $\begin{array}{c}1997 \\
(\mathrm{tc}=31 \%)\end{array}$ & $£ 690.0$ & $£ 517.5$ & $£ 862.5$ & $\begin{array}{c}1997 \\
(\mathrm{tc}=31 \%)\end{array}$ & $£ 552.0$ & $£ 414.0$ & $£ 690.0$ \\
\hline
\end{tabular}


exempt shareholders were $£ 690[=£$ $1000(1-0.31)(1-0 \%)]$. Hence, the lower the corporate tax, other factors held constant, the greater the dividend income received by shareholders. The shareholders would then pay personal tax on the dividend received.

Under the U.K. imputation system, stockholders receive net dividends (of imputation rate), $d$, plus a tax credit equal to the imputation rate $(s)$ times gross dividends; or the amount received by stockholders is $\mathrm{D}=d /(1-s)$. For instance, each stockholder receives cash dividends of $£ 0.8$ per share, and the company pays $£ 0.2$ per share in ACT (Advanced Corporation Tax $=20$ percent). Actually, an individual stockholder receives $£ 0.8(d)$ along with a tax credit of $£ 0.2(s)$ representing the ACT paid on their behalf; thus the amount received by a shareholder is $\mathrm{D}$ $=£ 0.8 /(1-0.2)=£ 1$.

In Table 2, the shareholders in 1996 would receive gross dividends of $£ 837.5[=£ 1,000$ (1-tc)/(1-s)]; where the corporate tax $(\mathrm{tc})=33$ percent and the imputation rate $(\mathrm{s})=20$ percent. A tax-paying shareholder would be liable to personal income tax (m) such that the shareholder actually receives $£ 1,000(1-\mathrm{tc})(1-\mathrm{m}) /(1-\mathrm{s})$. If a shareholder is exempt from tax $(\mathrm{m}=0 \%)$, she is effectively receiving a dividend of $£ 837.5$. [ $=£ 1,000(1-0.33)(1-0.0) /$ (1-0.20)]. Under this system, the taxexempt stockholders receive tax credit from the U.K. government.

Basic-rate shareholders would receive net dividend income of $£ 670$. $[=£ 1,000(1-0.33)(1-0.20) /(1-0.20)]$. In this system, the basic-rate shareholders will pay the same tax because the ACT or rate of imputation ( $\mathrm{s}=20 \%)$ is set equal to the basic rate of tax on dividend income $(\mathrm{m}=20 \%)$; thus the additional tax liability or refund equals zero.

If the stockholders are higher-rate taxpayers $(m>s)$, more taxes will be levied because the tax credit will not completely satisfy their income tax liability. The additional tax liability is equal to $(m-s)$ D. In 1996, the top rate taxpayers $(\mathrm{m}=40 \%)$ paid an additional tax liability of $£ 167.5$ [(40\% $20 \%$ ) $£ 837.5$ ] to the Inland Revenue Service. Accordingly, the top rate taxpayers received the net dividend income of $£ 502.5[=(£ 670-£ 167.5)$ or $=$ $(£ 1,000)(1-0.33)(1-0.40) /(1-0.20)]$.

If we compare the dividend incomes under the two tax regimes in Table 2, it can be summarized that the dividend income under the imputation system is greater than that under the classical system. The rationale behind this fact is that the distributed profits (dividends) under the classical system are subject to double taxation (corporation tax and income tax), whereas the imputation system provides shareholders with credit for tax paid by the company, and this credit can be used to reduce their income tax liability on dividends. Under the imputation system, part of the firm's tax liability is imputed to the shareholders and regarded as a prepayment of their income tax on dividends.

Under the imputation tax system, different types of stockholders may 
Basuki-The Response of Corporate Dividend Policy to The Abolition of Tax ...

have different tax preferences against and for dividends. The stockholders may receive capital gains if the company does not pay out dividends. If capital gain tax rate is $z$, and stockholders receive capital gains of $£ 1$, then the after-tax amount received will be (1$z$ ). In this situation, stockholders prefer dividends only if the value of aftertax dividends is greater than the value of after-tax capital gains; that is $\{(1-$ $\mathrm{m}) /(1-\mathrm{s})\}>(1-\mathrm{z})$. On the contrary, capital gains will be preferred to dividends if: $(1-\mathrm{z})>\{(1-\mathrm{m}) /(1-\mathrm{s})\}$. (Chui et al. 1992).

Since July 1997, pension providers and most of the U.K. corporate shareholders (including authorized unit trusts) have no longer been entitled to the payment of related tax credit. Hence, the incentive to receive dividends for tax-exempt shareholders has declined significantly. In the budget speech on July 2, 1997, Mr. Gordon Brown, the Chancellor of the Exchequer, said:

The present system of tax-credits encourages companies to pay out dividends rather than reinvest their profits. This cannot be the best way of encouraging investment for the long term as was acknowledged by the last government. Many pension funds are in substantial surplus and at present many companies are enjoying pension holidays, so this is the right time to undertake longneeded reform. So, with immediate effect, I propose to abolish tax credits paid to pension funds and companies. [Budget Statement 1997. HANSARD-Parliamentary Debate, House of Commons Official Report 297 (33): 306.

Historically, pension funds, which are tax-exempt, could receive a refund (tax credit) on their dividend income. The tax credit given to pension funds reduces overall tax revenues of the U.K. government. If the dividend had not been paid, the tax revenues would have been higher. Therefore, this payment to pension funds represents not only a tax exemption, but also a partial refund of corporation tax. The imputation system provides the pension funds and other tax-exempt shareholders with tax advantage which may contribute to the increase of dividend payment.

If a dividend is paid on or after July 2, 1997, pension providers and most the U.K. corporate shareholders (including authorized unit trusts) will no longer be entitled to payment of related tax credit. The U.K. government also eliminated the ACT refund for other zero-rate taxpayers starting in 1999. However, tax credit would continue to be payable to charities and some other tax-exempt institutions until 1999 when they were gradually eliminated over a period of five years. Another government's proposal would reduce the tax credit rate from 20 percent to 10 percent in 1999. At the same time, the government has proposed to decrease the corporate tax rate from 33 percent to 31 percent.

Table 3 shows the effective rate of income tax received by shareholders 
Gadjah Mada International Journal of Business, May - August 2007, Vol. 9, No. 2

Table 3.Effective Rate of Income Tax Before and After the 1997 Abolition of Tax Credit on Dividend

\begin{tabular}{|c|c|c|c|c|}
\hline \multicolumn{5}{|c|}{ Effective Rates of Income Tax } \\
\hline \multirow[b]{2}{*}{ Shareholders } & \multicolumn{2}{|c|}{$\begin{array}{c}\text { Before the Abolition of } \\
\text { Tax Credit }\end{array}$} & \multicolumn{2}{|c|}{$\begin{array}{l}\text { After the Abolition of } \\
\text { Tax Credit }\end{array}$} \\
\hline & $\begin{array}{l}\text { Dividend } \\
\text { Income Tax }\end{array}$ & $\begin{array}{l}\text { Capital } \\
\text { Gain Tax }\end{array}$ & $\begin{array}{l}\text { Dividend } \\
\text { Income Tax }\end{array}$ & $\begin{array}{c}\text { Capital } \\
\text { Gain Tax }\end{array}$ \\
\hline Tax-exempt & $-25 \%$ & $0 \%$ & $0 \%$ & $0 \%$ \\
\hline Basic rate & $0 \%$ & $\leq 23 \%$ & $0 \%$ & $\leq 23 \%$ \\
\hline Top rate & $25 \%$ & $\leq 40 \%$ & $25 \%$ & $\leq 40 \%$ \\
\hline
\end{tabular}

under the imputation tax system before and after the 1997 abolition of tax credit on dividends. Table 4 (a) and 4 (b) provide examples of the calculation for the effective rate before and after the abolition of tax credit. Suppose a shareholder receives net dividends (d) of $£ 100$ and the rate of imputation $(s)$ is 20 percent, then the gross dividends $(D)$ would be $£ 125[=£ 100 /$ $(1-20 \%)]$. If the stockholder is tax exempt $(\mathrm{m}=0)$, she will receive tax credit from the U.K. government, and the tax refund will be equal to $£ 25$. Before the abolition of tax credit, she would receive total dividends of $£ 125$ $(£ 25+£ 100)$. The effective rate for the tax-exempt shareholder would be (-) 25 percent. However, after the 1997 abolition of tax credit, she is no longer entitled to the payment of tax credit, and the effective rate of income tax increases to 0 percent and she will only receive dividends of $£ 100$. Therefore, the amount of dividends received by tax-exempt shareholders (pension funds) declines significantly from $£ 125$ to $£ 100$ after the abolition of the tax credit.

If the stockholders are top-rate taxpayers, more taxes will be levied since the tax credit will not completely satisfy their income tax liability. The additional tax liability will be equal to $(\mathrm{m}-\mathrm{s}) \mathrm{D}=(40 \%-20 \%) £ 125=£ 25$. Hence, before the abolition of tax credit, the effective rate of income tax was 25 percent $(=£ 25 / £ 100)$. After the abolition, the effective rate of top-rate shareholders remains unchanged.

If the stockholder is a basic-rate taxpayer, the rate of $\mathrm{ACT}$ is set equal to the basic rate of tax on dividend income or $(m=s)$, thus the additional tax liability or refund equals zero. Before and after the 1997 abolition of tax credit on dividends, the effective rate of dividend income for the basic-rate shareholders remains the same $(0 \%)$.

In the U.K., capital gains are taxed at income tax rate. However, the effective rate on capital gains is likely to be 
Basuki-The Response of Corporate Dividend Policy to The Abolition of Tax...

Table 4 (a).Effective Rate of Dividend Income Tax Before the 1997 Abolition of Tax Credit

Effective Rate of Dividend Income Tax Before the Abolition

\begin{tabular}{|c|c|c|c|}
\hline & $\begin{array}{c}\text { Tax Exempt } \\
m=0 \%\end{array}$ & $\begin{array}{l}\text { Basic Rate } \\
\mathbf{m}=\mathbf{2 0} \%\end{array}$ & $\begin{array}{l}\text { Top Rate } \\
\mathrm{m}=\mathbf{4 0} \%\end{array}$ \\
\hline Net Dividend $=\mathrm{d}=£ 100$ & $£ 100$ & $£ 100$ & $£ 100$ \\
\hline Gross Div : $\mathrm{D}=\mathrm{d} /(1-\mathrm{s})$ & $£ 125$ & $£ 125$ & $£ 125$ \\
\hline Tax Credit $=\mathrm{s}$ & $20 \%=£ 25$ & $20 \%=£ 25$ & $20 \%=£ 25$ \\
\hline $\begin{array}{l}\text { Statutory Rate }=\mathrm{SR} \\
(\mathrm{SR}=\mathrm{m} \times \mathrm{D})\end{array}$ & $\begin{array}{c}0 \% \times \text { Gross } \\
\text { Dividend }=£ 0\end{array}$ & $\begin{array}{c}20 \% \times \text { Gross } \\
\text { Dividend }=£ 25\end{array}$ & $\begin{array}{c}40 \% \times \text { Gross } \\
\text { Dividend }=£ 50\end{array}$ \\
\hline $\begin{array}{l}\text { Additional Tax Liability } \\
\text { or Refund ATL= } \\
\text { (SR }- \text { Tax Credit) }\end{array}$ & $\begin{array}{l}\text { Refund from } \\
\text { Inland Revenue } \\
\quad=\mathbf{-} \mathbf{2 5}\end{array}$ & $\begin{array}{l}\text { Additional Tax } \\
\text { Payment } \\
=£ 0\end{array}$ & $\begin{array}{l}\text { Additional Tax } \\
\text { Payment } \\
=£ 25\end{array}$ \\
\hline $\begin{array}{l}\text { Dividends Received } \\
\text { by Shareholders= } \\
(\mathrm{d}-\mathrm{SR}+\mathrm{s})\end{array}$ & $£ 125$ & $£ 100$ & $£ 75$ \\
\hline $\begin{array}{l}\text { Thus, Effective } \\
\text { Tax Rate = ATL / d }\end{array}$ & $-25 \%$ & $0 \%$ & $25 \%$ \\
\hline
\end{tabular}

Table 4 (b). Effective Rate of Dividend Income Tax After the1997 Abolition of Tax Credit

Effective Rate of Dividend Income Tax After the Abolition

\begin{tabular}{|c|c|c|c|}
\hline & $\begin{array}{c}\text { Tax Exempt } \\
m=0 \%\end{array}$ & $\begin{array}{l}\text { Basic Rate } \\
\mathbf{m}=\mathbf{2 0} \%\end{array}$ & $\begin{array}{l}\text { Top Rate } \\
m=40 \%\end{array}$ \\
\hline Net Dividend $=\mathrm{d}=£ 100$ & $£ 100$ & $£ 100$ & $£ 100$ \\
\hline Gross Div : $\mathrm{D}=\mathrm{d} /(1-\mathrm{s})$ & $£ 125$ & $£ 125$ & $£ 125$ \\
\hline Tax Credit $=\mathrm{s}$ & $0 \%=£ 0$ & $20 \%=£ 25$ & $20 \%=£ 25$ \\
\hline $\begin{array}{l}\text { Statutory Rate }=\text { SR } \\
(\mathrm{SR}=\mathrm{m} \times \mathrm{D})\end{array}$ & $\begin{array}{c}0 \% \text { x Gross } \\
\text { Dividend }=£ 0\end{array}$ & $\begin{array}{c}20 \% \times \text { Gross } \\
\text { Dividend }=£ 25\end{array}$ & $\begin{array}{c}40 \% \times \text { Gross } \\
\text { Dividend }=£ 50\end{array}$ \\
\hline $\begin{array}{l}\text { Additional Tax Liability or } \\
\text { ATL = } \\
\text { (SR - Tax Credit) }\end{array}$ & $\begin{array}{l}\text { Refund from } \\
\text { Inland Revenue } \\
\quad=\mathfrak{£} \mathbf{0}\end{array}$ & $\begin{array}{l}\text { Additional Tax } \\
\text { Payment } \\
=£ 0\end{array}$ & $\begin{array}{l}\text { Additional Tax } \\
\text { Payment } \\
=£ 25\end{array}$ \\
\hline $\begin{array}{l}\text { Dividends Received by } \\
\text { Shareholders }= \\
(d-S R+s)\end{array}$ & $£ 100$ & $£ 100$ & $£ 75$ \\
\hline $\begin{array}{l}\text { Thus, Effective Tax Rate= } \\
\text { ATL / d }\end{array}$ & $0 \%$ & $0 \%$ & $25 \%$ \\
\hline
\end{tabular}


Gadjah Mada International Journal of Business, May - August 2007, Vol. 9, No. 2

significantly lower than the income tax rate as the capital gains are taxed only on realization, thereby reaping the benefits of payment deferral, various allowances, and indexation (Lasfer 1995). For instance, in 1999, each of a husband and wife 'living together' has the benefit of annual capital gains exemption of $£ 7,100$ when shares are sold. A shareholder is also entitled to an indexation allowance, which provides protection from the effect of inflation.

Suppose the effective rate of capital gains tax for top-rate shareholders is 20 percent (see Table 3: Capital gains tax $\leq 40 \%$ ) and if the stockholders receive capital gains of $£ 100$, then the after-tax capital gains will be $£ 80$ $[=£ 100(1-20 \%)]$. In this case, the toprate stockholders will prefer capital gains since the value of after-tax capital gains ( $£ 80)$ is greater than the value of after-tax dividends ( $£ 75$; effective rate of dividend income $=25 \%$ ).

As can be seen from Table 3, 4(a) and 4(b), the 1997 Abolition of Tax Credit has decreased the attractiveness of dividend income relative to capital gains for the group of shareholders whose dividend income is not taxed (tax-exempt security holders). These shareholders, such as pension funds, experience a sharp increase in their effective tax rate on dividends from 25 percent in the period before the abolition of tax credit to zero percent following the new tax regulation. Accordingly, this tax regulation may induce these shareholders to shift their preference for dividends towards capi- tal gains. This change in the effective taxation of capital gains and dividends at the level of the security holders may finally affect corporate dividend policy.

\section{Research Objective}

The study of corporate dividend policy under market imperfection has long been the subject of theoretical and empirical research. Any change in an imperfection may lead to a shift in the market equilibrium, and this provides an opportunity to examine equilibrium theories. One such event is the 1997 abolition of tax credit on dividends, the major change in the tax position of the U.K. companies (pension funds). The abolition of the tax credit on dividends will remove a distortion in the tax system which encourages the distribution of earnings as dividends rather than their retention. A high dividend payout may reduce the availability of low-cost internal source of fund, and this could decrease the level of investment expenditures. Hence, the U.K. government attempts to harness the tax system to encourage lower dividends and larger reinvestment.

The traditional differential taxation of capital gains and dividends has generated a controversy with regard to the valuation of firm equity and the setting of dividend policy.

The 1997 abolition of tax credit on dividends provides an opportunity to test whether tax affects corporate dividend policy. If a company's management perceives investors to have a tax-induced preference that may influ- 
Basuki-The Response of Corporate Dividend Policy to The Abolition of Tax ...

ence the valuation of equity, then changes in the effective taxation of capital gains and dividends should affect the corporate dividend policy. This study tests the prediction that the abolition of tax credit on dividends is followed by a decrease in the aggregate dividend payment in the postabolition period.

Through the abolition of tax credit paid to pension funds and companies, combined with a decrease in the corporate tax burden from 33 percent to 31 percent in 1997, the U.K. government attempts to utilize a tax system to encourage lower dividends and greater reinvestment. The 1997 abolition of tax credit on dividends presents a changing tax scenario in which theories of dividend can be examined empirically.

The objective of this study is to determine whether the aggregate dividend payment changes as a result of the 1997 abolition of tax credit on dividends. Tax-clientele theories suggest that the tax penalty on dividends suppresses the aggregate dividend payment. This study tests whether corporate dividend policy is set to suit the tax clientele by looking at the effect of the 1997 abolition of tax credit on aggregate dividend payment.

\section{Literature Review}

Following the study of Miller and Modigliani (1961) which demonstrates the dividend irrelevance in the perfect capital markets, numerous studies have been conducted to explain the divi- dend payment in the light of market imperfections in the form of taxation. Miller and Modigliani argue that the value of the firm is determined by its earnings power and risk, and thus the firm's value depends on its investment policy rather than the proportion of earnings distributed as dividends. This review focuses on the literature relevant to this empirical study: (1) behavioral model of dividend policy and (2) theories and evidence of the tax clientele dividend equilibrium.

\section{The Behavioral Model of Dividend Policy}

Corporate dividend policy involves the decision to pay out profits versus retaining them for reinvestment in the company. There are a number of factors that may influence a firm's dividend policy, including the profit level, the stability of earnings, the volume of good investment opportunities available, the tax position of shareholders, and legal considerations.

In 1956, Lintner conducted interviews with 28 companies to investigate their thoughts on the determination of dividend policy. His study suggests that corporate managers focus on the change in the existing rate of dividend payout, not on the amount of the newly established payout as such. Most companies seek to avoid making changes in their dividend rates that may have to be reversed within a year or so. Generally, investment requirements have little effect on modifying the pattern of dividend behavior. More- 
over, major changes in earnings which are 'out of line' with the existing dividend rate are the most important determinants of a firm's dividend decision.

In his study, companies tended to make periodic partial adjustments towards a target dividend payout ratio rather than dramatic changes in payout since corporate managers believed that stockholders preferred a steady stream of dividends. Lintner's study suggests that two parameters describe dividend policy: (1) the target dividend payout ratio and (2) the speed of adjustment of current dividends to the target dividends. His model of corporate dividend policy is as follows:

$$
D_{t}-D_{t-1}=a+s\left(E_{t}-D_{t-1}\right)+u
$$

where: $D_{t}=$ current dividends,

$\mathrm{D}_{\mathrm{t}-1}=$ lagged dividends,

$\mathrm{a}=$ constant,

$\mathrm{E}_{\mathrm{t}}=$ current earnings,

$\mathrm{s}$ = speed of adjustment coefficient,

$\mathrm{r}$ = target dividend payout ratio, and

$\mathrm{u}_{\mathrm{t}}=$ unexplained error term.

In this model, dividends are assumed to be based on earnings after tax, and are assumed to be adjusted slowly to a change in earnings. Companies are perceived as pursuing a target dividend payout ratio (r), which is applied to current earnings $\left(\mathrm{E}_{\mathrm{t}}\right)$. If dividends are fully adjusted each year to achieve the target payout level $\left(\mathrm{r} \mathrm{E}_{\mathrm{t}}\right)$, they will change by $\left(\mathrm{rE}_{\mathrm{t}}-\mathrm{D}_{\mathrm{t}-1}\right)$, be- tween period $t$ and $t-1$. A conservative company will have a low adjustment rate while a less conservative company will have a high adjustment rate, captured in the speed of adjustment coefficient(s). For instance, if the speed of adjustment, $s=0$, and constant term $a=0$, so $D_{t-1}=D_{t}$; whereas if $s=1$ and $a=0$, the actual change in dividends will be equal to the target change in dividends. The constant term $a$ is added to allow for company's reluctance to cut dividends. If $a$ is positive, Lintner's model shows that dividends will be inclined to move upward even if none of the other terms changes. Hence, current dividends $\left(D_{t}\right)$ must be below $D_{t-1}$ to offset the constant for a cut in dividends to be indicated.

Fama and Babiak (1968) reevaluated Lintner's model, and find that the partial-adjustment model proposed by Lintner continues to perform well relative to alternative specifications using both economywide earnings and dividend data. Several inter-temporal dividend models were tested in their study. For example, they examined a model involving additional lagged values, either or both of the earnings and dividendvariables, and the estimating equation is:

$$
\begin{aligned}
\mathrm{D}_{\mathrm{i}, \mathrm{t}}-\mathrm{D}_{\mathrm{i}, \mathrm{t}-1}= & \alpha_{\mathrm{i}}+\beta_{1 . i 1} \mathrm{D}_{\mathrm{i}, \mathrm{t}-1}+\beta_{2 \mathrm{i}} \mathrm{D}_{\mathrm{i}, \mathrm{t}-2} \\
& +\beta_{3 \mathrm{i}} \mathrm{E}_{\mathrm{t}, \mathrm{t}}+\beta_{4 \mathrm{i}} \mathrm{E}_{\mathrm{t}, \mathrm{t}-1}+\mathrm{u}_{\mathrm{i}, \mathrm{t}}
\end{aligned}
$$

This regression model was applied to each of the 392 companies (time series data from 1947 to 1964). The results show that adding the lagged dividend 
Basuki-The Response of Corporate Dividend Policy to The Abolition of Tax ...

$D_{t-2}$ does not improve upon the explanation of annual dividend changes provided by the Lintner's model. The mean and median values of adjusted $R$-square for the two models are almost identical. For the lagged earnings variable $E_{t-1}$, the results seem to indicate that lagged earnings do not have significant explanatory power, presumably due to multicollinearity between $E_{t}$ and $E_{t-1}$. The statistical results show that $t$-value of the coefficient of $E_{t}$ declines substantially when $E_{t-1}$ is incorporated into the model.

Finally, Fama and Babiak conclude:

The regressions on the firm data, the simulations, and the prediction tests provide consistent evidence on dividendmodels for individual firms. The two-variable Lintner model, including a constant term, $D_{t-1}$ and $E_{t}$, performs well relative to other models; in general, however, deleting the constant and adding the lagged profits variable $E_{t-1}$ leads to slight improvement in the predictive power of the model. In applying dividend models to the data of most firms, net incomeseems to provide a bettermeasure of profits than either cash flow or net income and depreciation included as separate variables in the model. Finally, in the model tested here, serial dependence in disturbances does not seem to be a serious problem (p. 1160).

Theobald (1978) conducted an empirical study on the dividend behavior using the U.K. data, and the following three intertemporal dividend models were tested:

$$
\begin{aligned}
& \text { model } 1: \mathrm{D}_{\mathrm{t}}-\mathrm{D}_{\mathrm{t}-1}=\alpha+\beta_{1} \mathrm{E}_{\mathrm{t}}+ \\
& \beta_{2} D_{t-1}+u_{t}
\end{aligned}
$$

model 2: $\mathrm{D}_{\mathrm{t}}-\mathrm{D}_{\mathrm{t}-1}=\alpha+\beta_{1} \mathrm{E}_{\mathrm{t}}+$

$$
\begin{aligned}
& \beta_{2} D_{t-1}+\beta_{3} D_{t-2} \\
& +u_{t}
\end{aligned}
$$

model 3: $\mathrm{D}_{\mathrm{t}}-\mathrm{D}_{\mathrm{t}-1}=\alpha+\beta_{1} \mathrm{E}_{\mathrm{t}}+$

$$
\begin{aligned}
& \beta_{2} D_{t-1}+\beta_{4} E_{t-1} \\
& +u_{t}
\end{aligned}
$$

$$
\text { where: } \begin{aligned}
\alpha & =\text { constant, } \\
\mathrm{D}_{\mathrm{t}} & =\text { current dividends, } \\
\mathrm{D}_{\mathrm{t}-1}= & \text { one-period lagged divi- } \\
& \text { dends, } \\
\mathrm{E}_{\mathrm{t}}= & \text { current earnings, } \\
\mathrm{E}_{\mathrm{t}-1}= & \text { one-period lagged earn- } \\
& \text { ings and } \\
\mathrm{u}_{\mathrm{t}}= & \text { error term. }
\end{aligned}
$$

These three models were applied to each of the 41 the U.K. companies for the period of 1964-1975 (12 years). The regression results show that in the model 1 , the mean parameter estimates for constant $(\alpha)$, current earnings $\left(E_{t}\right)$ and one-period lagged dividends $\left(\mathrm{D}_{\mathrm{t}-1}\right)$ coefficients have high t-values. In the model 2, the two-period lagged dividends variable $\left(\mathrm{D}_{\mathrm{t}-2}\right)$, on average, would not appear to improve the explanatory power of Lintner's model significantly (model 1). Furthermore, the mean $t$ value of $\beta_{3}$ is low and the mean t-value 
Gadjah Mada International Journal of Business, May - August 2007, Vol. 9, No. 2

of $\beta$ declines in the model 2. This reduction of the $t$-values for the oneperiod lagged dividends variable $\left(D_{t-1}\right)$ indicates that additional multicollinearity is present in this model since the two lagged dividends variables $\left(D_{t-1}\right.$ and $\mathrm{D}_{\mathrm{t}-2}$ ) are incorporated in this equation.

However, model 3 has a mean of $\mathrm{R}$-square which is substantially higher than that of model 1. Again, an additional multicollinearity is confirmed by reducing the $t$-values for the current earnings $\left(E_{t}\right)$ and lagged dividends variables $\left(D_{t-1}\right)$ after introducing oneperiod lagged earnings into the model 3. A multicollinearity is almost prevalent in time-series data, and since $E_{j, t}$ and $E_{j, t-1}$ are correlated, this would increase the standard errors of the parameter estimates, thereby reducing the $t$-values.

Theobald finally concludes that the most important result of the study has been its confirmation of the expected instability and disorientation introduced from 1973 onwards in the firm dividend decision by inflation, dividend restraint and introduction of Advanced Corporation Tax. The time series work (Section IV a) provided relatively strong insights into the intertemporal dividend behavior of firms for the period 1964 to 1974. This result is somewhat surprising in view of the structural changes present in the latter two periods of the sample. The structural changes could cause the disturbance term to have a nonzero expected value with the result that the parameter estimates would be biased, but there does not appear to be a clear cut reason why such well defined parameters, in terms of t-statistics, should have been obtained. (p.134)

Following the spirit of Lintner's study, Baker et al. (1985) conducted a survey of management views on dividend policy. They delivered questionnaires to chief financial officers of 562 companies listed on the New York Stock Exchange representing three industry groups: (1) electric utility, (2) manufacturing, and (3) wholesale/retail. The first objective of their study was to examine how well Lintner's model described current practice. The respondents were asked to indicate the importance of each of 15 factors in determining their companies' actual dividend policy. The findings document that the same four determinants are considered the most important by the three groups. The most highly ranked determinants are the anticipated level of a company's future earnings and the pattern of past dividends. The high ranking of these two factors is consistent with Lintner's results.

The third important factor in determining dividend policy is cash availability. Lintner did not directly mention this determinant. However, Van Horne (1983) and Brigham and Gapenski (1987) note that the level of cash holding is an important determinant for managerial dividend choices. The fourth major determinant is concerned about maintaining or increasing share price. This is particularly 
Basuki-The Response of Corporate Dividend Policy to The Abolition of Tax ...

strong among utility companies that rank this factor the second in importance.

Moreover, they observe significantly different attitudes towards corporate dividend policy among the three industry groups. The differences occur primarily as a result of the responses of utility managers. They conclude that these differences may be due to regulations. For instance, since regulations provide utilities with monopoly power over a product which enjoys steady demand, their earnings are relatively stable. Therefore, their risk of reducing dividends owing to an unexpected decline in earnings is less than that of other companies.

According to Baker et al. (1985), regulation per se makes the behavior of managers in this group different from that of other groups. Regulation leads corporate managers to be more concerned with maintaining or increasing share price, with maintaining target capital structure, and with the cost of raising external funds. On the other hand, corporate managers are less concerned with the availability of profitable investment opportunities for the company, and with projections concerning the future state of the economy. Hence, it is plausible that the dividend policy of regulated companies differs from that of non-regulated companies.

Benito and Young (2003) conducted a study on dividend omissions and dividend cuts by British companies to answer a question on what financial situations determine whether a firm pays a dividend or not. They used probit model to examine the relationship between probability of a dividend omission or a dividend cut and the financial characteristics such as cash flow level, leverage, investment opportunities, actual investment, and real sales. Companies with a high level of cash flows are less likely to cut dividends while high level of leverage increases the probability. A high level of investment is negatively related to the probability of cutting dividend payment; companies undertaking a high level of investments are quite confident about their future prospects and thereby less likely to cut/omit the dividends.

Using total sample of 2,963 companies during the period of 1974-1999, they identify an increase in proportion of the U.K. companies that omitted dividend payment from 1995, and this increase is largely accounted for by an increase in the proportion of companies that have never paid dividends. Benito and Young (2003) find that most of firms that have never paid dividends are relatively small firms with strong investment opportunities, and an increase in dividend omissions does not reflect balance sheet weakness. This change reflects "great expectation" rather than "hard times." They also find that there is little evidence to link the increase in omission to the major tax reform of 1997 that abolishes dividend tax credit to taxexempt investors.

Furthermore, Benito and Young (2003) argue that the low level of cash flows, greater opportunities for invest- 
Gadjah Mada International Journal of Business, May - August 2007, Vol. 9, No. 2

ments, and the high level of leverage are all associated with an increased propensity to omit dividends. In particular, those of cash flows and leverage are more strongly related to the propensity to cut dividends. This situation suggests that a dividend cut is a stronger indicator of financial fragility than dividend omission.

\section{The Tax Clientele Theories and Evidence}

The concept of dividend clientele was originally suggested by Miller and Modigliani (1961):

If for example the frequency distribution of corporate payou ratios happened to correspond exactly with the distribution of investor preferences for payout ratios, then the existence of these preferences would clearly lead ultimately to a situation whose implications were different, in no fundamental respect, from the perfect market case. Each corporation would tend to attract to itself a "clientele" consisting of those preferring its particular payout ratio, but one clientele would be entirely as good as another in terms of the valuation it would imply for the firm (page 431).

The problem brought to light by Miller and Modigliani rests in the different tax rates applied to dividend income and capital gains. One way to analyze this problem is to compare two companies (for instance, X Ltd. and Y Ltd.) identical in all aspects except that $X$ Ltd. pays dividends and $Y$ Ltd. does not pay dividends. In this context, the pre-tax one-year holding period returns for the two companies must be identical:

$R_{x}=R_{y}$,

$$
R_{x}=\left(\frac{D_{x}}{P_{x, t}}\right)+\left(\frac{P_{x, t+1}-P_{x, t}}{P_{x, t}}\right) \cdots
$$

and

$$
R_{y}=\left(\frac{P_{y, t+1}-P_{y, t}}{P_{y, t}}\right) \text {. }
$$

where:

$\mathrm{P}_{\mathrm{y}, \mathrm{t}+1}=$ share price in the year end for company $Y$

$\mathrm{P}_{\mathrm{y}, \mathrm{t}} \quad=$ share price at the beginning of the year for company $Y$

$\mathrm{P}_{\mathrm{x}, \mathrm{t}+1}=$ share price in the year end for company $X$

$\mathrm{P}_{\mathrm{x}, \mathrm{t}} \quad=$ share price at the beginning of the year for company $X$

$\mathrm{D}_{\mathrm{x}} / \mathrm{P}_{\mathrm{x}, \mathrm{t}}=\underset{X}{\text { dividend yield for company }}$

If different tax rates are applied to dividend income and capital gains, the after-tax returns would be:

$$
\begin{aligned}
R_{x, \text { after }-\operatorname{tax}} & \left(\frac{D_{x}}{P_{x, t}}\right)\left(1-t_{p}\right)+ \\
& \left(\frac{P_{x, t+1}-P_{x, t}}{P_{x, t}}\right)\left(1-t_{g}\right)
\end{aligned}
$$

and

$$
\mathrm{R}_{\mathrm{y}, \text { after - tax }}=\left(\frac{\mathrm{P}_{\mathrm{y}, \mathrm{t}+1}-\mathrm{P}_{\mathrm{y}, \mathrm{t}}}{\mathrm{P}_{\mathrm{y}, \mathrm{t}}}\right)\left(1-\mathrm{t}_{\mathrm{g}}\right)
$$


Basuki-The Response of Corporate Dividend Policy to The Abolition of Tax ...

where: $t_{g}=$ capital gains tax

$\mathrm{t}_{\mathrm{p}}=$ dividend income tax

In the aforementioned condition, the after-tax returns of the two companies are only equal when $t_{g}=t_{p}$. If $t_{p}>t_{g}$, then the after-tax return on company $Y$ is greater than that on company $X$, vice versa. A solution to this apparent problem was suggested by Miller and Modigliani (1961) that the tax clientele exists and that non-dividend-paying stocks are held by stockholders with $t_{p}>t_{g}$ while dividend-paying stocks are held by stockholders with $t_{p}<t_{g}$. This situation is commonly referred to as the tax-clientele hypothesis.

Different clienteles (groups) of stockholders prefer different dividend policy. For instance, stockholders such as retired individuals or pension funds often prefer dividend (current) income, thus they want the company to pay higher percentage of its earnings. Such stockholders are often in low or even zero income-tax bracket. Other shareholders prefer reinvestment since they have no need for current investment income.

The traditional view of tax-clientele theory holds that under tax disadvantage for dividends and full information, the dividend payment (dividend demand) is irrational. Probably a wealth-maximizing stockholder would prefer capital gains due to lower tax rate. Accordingly, a preference for dividends is not consistent with the assumption of utility maximization. Several studies have suggested alternative models under which this would not be the case. Shefrin and Statman (1984), for instance, argue that shareholders, rather than maximizing a utility function, maximize a value function that places a higher value on consistent dividend income than on capital gains. In their paper, Shefrin and Statman provide a psychological description of an individual shareholder's preference for cash dividends. They suggest various reasons for dividend payment. For instance, due to the lack of self-control, the individual shareholder finds a difficulty delaying consumption, so she wishes to impose constraints on her actions (as a rule). A shareholder who desires to conserve her wealth should not consume capital; she only consumes dividends. If this rule is established, consuming dividends becomes a standard procedure. Dividend payment of companies can be selected to conform to her consumption level. Even though tax may favor capital gains, shareholders may find cash dividends attractive, and thus they want to pay the appropriate premium.

Miller and Modigliani (1961) suggest that the aggregate dividend payment satisfies tax clienteles who prefer either capital gains or dividend income. The aggregate dividend payment serves to satisfy these tax clienteles. Predicated on this line of reasoning, Farrar and Selwyn (1967) and Brenan (1970) develop equilibrium models in which dividends exist to satisfy the tax clienteles. This study refers these models to as tax-clientele models. 
Gadjah Mada International Journal of Business, May - August 2007, Vol. 9, No. 2

Farrar and Selwyn assume that individuals attempt to maximize their after-tax income. Stockholders have two alternatives:(1) they can buy shares in a levered company, or (2) they can own stocks in an all-equity company and borrow in order to give personal leverage. The first alternative is the form of payment to be made by the company. The company can pay out earnings as dividends or allow stockholders to take their income in the form of capital gains. Stockholders must choose whether they want capital gains or dividends. The second alternative is the amount of corporate versus personal level of gearing that is desired.

If the company pays out all of its earnings as dividends, the stockholders will receive $Y_{i{ }^{\circ}}$

$$
Y_{\mathrm{id}}=\left\{\left(\mathrm{CF}-\mathrm{rD}_{\mathrm{c}}\right)\left(1-\mathrm{t}_{\mathrm{c}}\right)-\mathrm{rD}_{\mathrm{ip}}\right\}\left(1-\mathrm{t}_{\mathrm{ip}}\right)
$$

where: $\mathrm{Y}_{\mathrm{id}}=$ after-tax income to the $\mathrm{i}^{\text {th }}$ shareholder if earnings are received as dividends.

$\mathrm{CF}=$ company's cash flows from operations

$r=$ interest rate (borrowing rate) which is assumed to be equal for companies and individuals

$\mathrm{D}_{\mathrm{c}}=$ company's debt

$\mathrm{D}_{\mathrm{ip}}=$ individual debt

$\mathrm{t}_{\mathrm{ip}}=$ personal incometax rate

$\mathrm{t}_{\mathrm{c}}=$ corporate tax rate
In the above equation, all of company's after-tax earnings, $(\mathrm{CF}-\mathrm{r}$ $\left.D_{c}\right)\left(1-t_{c}\right)$, are assumed to be paid out as dividends. Income (before tax) received by stockholders is the dividends minus the interest on liability used to buy stocks.

Another alternative is the company can decide to pay no dividend. In this case, it is assumed that all gains are realized immediately by stockholders and taxed at capital gains rate. Aftertax income received by a stockholder is as follows:

$$
\begin{aligned}
Y_{\mathrm{ig}}= & \left\{\left(\mathrm{CF}-\mathrm{rD}_{\mathrm{c}}\right)\left(1-\mathrm{t}_{\mathrm{c}}\right)\left(1-\mathrm{t}_{\mathrm{g}}\right)\right\}- \\
& \mathrm{rD}_{\text {ip }}\left(1-\mathrm{t}_{\text {ip }}\right) \ldots \ldots \ldots \ldots \ldots \ldots \ldots \ldots \ldots \ldots \ldots \ldots \ldots \ldots \ldots
\end{aligned}
$$

where: $Y_{i g}=$ after-tax income to the shareholder if earnings are received as capital gains

$\mathrm{t}_{\mathrm{g}}=$ capital gains tax rate

In this situation, a shareholder pays capital gains tax on income from the company and subtracts after-tax interest expenses on personal liability. The company can translate cash flows into capital gains by repurchasing its stocks in the market. From the two equations above, the ratio of capital gains $\left(\mathrm{Y}_{\mathrm{ig}}\right)$ and dividend income $\left(\mathrm{Y}_{\mathrm{id}}\right)$ is as follows:

$\frac{\mathrm{Y}_{\mathrm{ig}}}{\mathrm{Y}_{\mathrm{id}}}=\frac{\left\{(\mathrm{CF}-\mathrm{rDc})\left(1-\mathrm{t}_{\mathrm{c}}\right)\left(1-\mathrm{t}_{\mathrm{g}}\right)\right\}-\mathrm{rD}_{\text {ip }}\left(1-\mathrm{t}_{\mathrm{ip}}\right)}{\left\{\left(\mathrm{CF}-\mathrm{rD}_{\mathrm{c}}\right)\left(1-\mathrm{t}_{\mathrm{c}}\right)-\mathrm{rD}_{\text {ip }}\right\}\left(1-\mathrm{t}_{\mathrm{ip}}\right)}$ 
Basuki-The Response of Corporate Dividend Policy to The Abolition of Tax ...

If the tax rate on capital gains is less than the personal income tax $\left(\mathrm{t}_{\mathrm{g}}<\right.$ $t_{i p}$ ), shareholders will prefer capital gains to dividend income for any positive operating cash flows or earnings. Thus, the ratio of the two income streams is greater than one if $t_{g}<t_{i p}$. In general, the best form of payment is the one that is subject to the least tax rate.

Farrar and Selwyn also discuss an issue of debt policy. The debt should be held by the party who has the highest marginal tax rate such that the greatest tax shield can be acquired from the deductible interest payment. In the environment where only corporate income is taxed, all debts should be held by a corporation. In the situation where both corporate income and personal income are taxed, and corporate income may be subject to effective taxation as capital gains: $t_{g}<t_{i p}$, all debts should be held by individuals.

If all earnings are paid out as dividends, the favorable tax treatment of capital gains is not relevant. In this case, the value of the company can be maximized by taking on maximum level of debt. This can be proved by taking the partial derivative of the following equation:

$$
\mathrm{Y}_{\mathrm{id}}=\left\{\left(\mathrm{CF}-\mathrm{rD}_{\mathrm{c}}\right)\left(1-\mathrm{t}_{\mathrm{c}}\right)-\mathrm{rD}_{\mathrm{ip}}\right\} \cdot\left(1-\mathrm{t}_{\mathrm{ip}}\right)
$$

By differentiating the equation with respect to personal debt $\left(D_{i p}\right)$ and corporate debt $\left(\mathrm{D}_{\mathrm{c}}\right)$, we obtain:

$$
\text { Personal debt : } \frac{\partial \mathrm{Y}_{\mathrm{id}}}{\partial \mathrm{D}_{\mathrm{ip}}}=-\mathrm{r} .\left(1-\mathrm{t}_{\mathrm{ip}}\right)
$$

$$
\begin{aligned}
\text { Corporate debt: } & \frac{\partial Y_{i d}}{\partial D_{c}}= \\
& -r\left(1-t_{c}\right)\left(1-t_{p}\right) \ldots .(14)
\end{aligned}
$$

From the results of the partial derivatives above, corporate debt is always cheaper than personal debt. A company can exploit its superior borrowing opportunities to get an access to a cheap source of funds.

If a company decides to pay no dividend, and all earnings are translated into capital gains, then the above generality disappears. By differentiating the following equation with respect to personal and corporate debt,

$\mathrm{Y}_{\mathrm{ig}}=\left\{(\mathrm{CF}-\mathrm{rD} \mathrm{c})\left(1-\mathrm{t}_{\mathrm{c}}\right)\left(1-\mathrm{t}_{\mathrm{g}}\right)\right\}-\mathrm{rD}_{\mathrm{ip}}\left(1-\mathrm{t}_{\mathrm{ip}}\right) \ldots(15)$

we can obtain:

Personal debt: $\frac{\partial Y_{\text {id }}}{\partial D_{\text {ip }}}=-r\left(1-t_{p}\right) \ldots(16)$

Corporate debt: $\begin{aligned} & \frac{\partial Y_{i d}}{\partial D_{c}}= \\ & -r\left(1-t_{c}\right)\left(1-t_{g}\right) \ldots(17)\end{aligned}$

The relative value of corporate tax and personal tax shields depends on the array of marginal tax rates, $t_{g}, t_{i p}$, and $t_{c}$ faced by individual shareholders. If capital gains tax is zero $\left(\mathrm{t}_{\mathrm{g}}=0\right)$, then personal debt will be preferred to corporate debt by shareholders who are in marginal tax brackets higher than the marginal tax of the company. 
Brennan (1970) extends the study of Farrar and Selwyn into a general equilibrium model where shareholders or investors are assumed to maximize their expected utility of wealth. His conclusion on dividend payout is: "for a given level of risk, investors require a higher total return on a security the higher its prospective dividend yield is, because of the higher rate of tax levied on dividends than on capital gains." This statement suggests that dividend payout should be included as the second factor in the CAPM (Capital Asset Pricing Model) to explain the equilibrium rate of return on securities. The equilibrium relationship is given by:

$$
E\left(R_{i}-R_{f}\right)=\alpha_{0} \beta+\alpha_{1}\left(D Y_{i}-R_{f}\right)
$$

where $R_{i}$ is the before-tax rate of return on security $i, b$ is systematic risk, $D Y_{i}$ is dividend yield on security $i$, and $R_{f}$ is the risk-free rate. The model is derived under the assumption of unrestricted short sales and unlimited lending and borrowing at the risk-free rate.

Empirical investigation on the taxclientele theory can be classified into three main groups. The first group of the empirical tests has focused on the behavior of dividend-paying shares using the Capital Asset Pricing Model incorporating a dividend coefficient. The second group has examined the implied tax rate reflected in the exdividend day price behavior while the third group has studied the aggregate dividend payment following a change in the capital gains tax relative to the dividend income tax rate.

This study is focused on the third group which is relevant to this empirical research. Poterba (1987) conducted a study to test whether dividend payout policy responds to a change in the relative tax burden on capital gains and dividends in U.S. market. He finds that an increase in the capital gains tax rate relative to the dividend tax rate results in an increase in the aggregate dividend payment.

His model is based on the partialadjustment framework proposed by Lintner (1956). His analysis is focused on the logarithm of aggregate real dividends, and the target dividend level $\left(D^{*}\right)$ is assumed to be a constant-elasticity function of equity earnings (E). The after-tax income is associated with one dollar of dividend payout relative to one dollar of corporate retention with resulting capital gains $(\theta)$. The estimating equation is as follows:

$$
\begin{aligned}
\ln \left(D^{*}\right)= & \alpha_{0}+\alpha_{1} \ln (\mathrm{E})+ \\
& \alpha_{2} \ln (\theta) \ldots \ldots \ldots . .(18)
\end{aligned}
$$

His model for the annual percentage change in real dividends is obtained by combining this steady-state specification with flexible short-term dynamics, and the equation is:

$$
\begin{aligned}
\Delta \ln \left(\mathrm{D}_{\mathrm{t}}\right)= & \beta_{0}+\beta_{1} \Delta \ln \left(\mathrm{E}_{\mathrm{t}}\right)+ \\
& \beta_{2} \Delta \ln \left(\theta_{\mathrm{t}}\right)+ \\
& \beta_{3}\left[\ln \left(\mathrm{D}_{\mathrm{t}-1}\right)-\right. \\
& \left.\ln \left(\mathrm{D}_{\mathrm{t}-1}^{*}\right)\right]+\varepsilon_{\mathrm{t}}
\end{aligned}
$$


Basuki-The Response of Corporate Dividend Policy to The Abolition of Tax ...

In this model, the dependent variable, $\Delta \ln \left(\mathrm{D}_{\mathrm{f}}\right)$, is the logarithmic change in real dividend payment by domestic companies. Some different measures of earnings $\left(E_{t}\right)$ are utilized to explain the target dividends, for instance aftertax company profits (unadjusted earnings) and earnings adjusted for inventory valuation.

The ratio of after-tax income or tax preference parameter $\left(\theta_{t}\right)$ is a weighted average across stockholders of the after-tax income associated with corporate dividend payout, divided by the after-tax income associated with undistributed profits:

$$
\theta_{\mathrm{t}}=\sum_{\mathrm{t}=1}^{\mathrm{s}} \mathrm{w}_{\mathrm{it}} \frac{\left(1-\mathrm{m}_{\mathrm{it}}\right)}{\left(1-\mathrm{z}_{\mathrm{it}}\right)\left(1-\tau_{\mathrm{it}}\right)} \ldots \ldots . .(19)
$$

where, $\mathrm{S}=$ number of distinct shareholder classes

$\mathrm{m}_{\mathrm{it}}=$ marginal dividend tax rate on shareholders in class $i$

$\tau_{\mathrm{it}}=$ tax rate on undistributed profits

$\mathrm{z}_{\mathrm{it}}=$ accrual-equivalent capital gains tax rate

Poterba's findings indicate the importance of tax policy for corporate dividend payout. The estimated tax effects are statistically significant and similar across various specifications; one percent increase in the ratio of after-tax dividend income to after-tax capital gains income $\left(\theta_{t}\right)$ results in an increase in the real dividends $\left(D_{t}\right)$ about 0.66 percent in short term. In addition, the long-term effect of such a dividend tax decrease is a two percent to three percent dividend payout increase.

His results also show that the 1986 Tax Reform Act in the U.S. lowered marginal dividend tax rates for most shareholders while increasing the tax burden on capital gains, and these changes have encouraged companies to increase the dividend payout ratio.

Feldstein (1970) conducted research to examine whether dividend payout policy responds to a change in the tax incentive during the period from 1953 to 1964 in the U.K. market. The dividend equations estimated in his study are the generalization of Lintner's model (1956). His model assumes that optimum dividends $\left(D_{t}\right)$ reflect the company's level of earnings $\left(E_{t}\right)$, the tax-determined opportunity cost of one pound of retained earnings in terms of the forgone net dividends $\left(\theta_{t}\right)$, and disturbance terms.

The dividend equation is given:

$$
\begin{aligned}
\ln \mathrm{D}_{\mathrm{t}}-\ln \mathrm{D}_{\mathrm{t}-1}= & \lambda \alpha+\lambda \alpha \ln \mathrm{E}_{\mathrm{t}}+ \\
& \lambda \mathrm{b} \ln \theta_{\mathrm{t}}-\lambda \ln \mathrm{D}_{\mathrm{t}-1}+ \\
& \mathrm{w}_{\mathrm{t}} \cdots \ldots \ldots \ldots \ldots \ldots \ldots \ldots \ldots \ldots \ldots \ldots
\end{aligned}
$$

where $\lambda$ is a response elasticity approximated by the partial adjustment model.

His results show that the differential profit tax has a substantial impact on dividend level. Changes in tax rate affect both the ratio of maximum net profits to gross profits and the opportunity cost of retained earnings in terms of forgone dividends. Dividends respond to these changes with the distributed lag; between 40 percent and 
60 percent of the ultimate effect occur in the first year.

Khoury and Smith (1977) conducted a study to observe how the dividend policies of Canadian companies were affected by a change in tax structure -the imposition of capital gains tax in Canada in January 1972. Their results are consistent with the thesis that the aggregate supply of dividends is sensitive to the differential between capital gains and ordinary income taxes. They utilized the partial adjustment dividend model of Lintner (1956) to obtain a dividend forecast for Canadian firms. The hypothesis that dividend policies of Canadian firms do not change after the introduction of the capital gains tax is rejected. Canadian companies significantly increase their dividend payout after the introduction of capital gains tax for the first time in 1972. The average percentage dividend change doubled from 5 percent during the prior years (1963-1971) to 10.1 percent in the subsequent two years (1972-1973).

\section{Sample and Data}

In this study, sample is comprised of 121 U.K. companies drawn from the Datastream International (FT All Shares). These companies are derived from 20 industry groups, and for a company to be included in this sample, it has to satisfy the following criteria: first, it did not file for bankruptcy during the period of 1974-1999, and second, the requisite data, which are cash dividends and earnings, of each company are available for the whole period of 1974-1999.

Annual cash dividends and earnings were collected for each company. Dividends and earnings were then adjusted for stock splits and stock dividends. Dividend payout ratios were calculated from annual dividends and earnings per share. In those years for which companies had negative earnings, the companies' dividend payout ratios could not be computed. Of the 129 companies in the original sample, 8 companies were excluded due to negative earnings or zero dividends. Hence, the number of companies in this study is 121 companies, and these companies come from 20 industry groups (sectors).

To show a preliminary view of the time-series behavior of pertinent variables in this study, Figure 1 and Figure 2 graphically present dividend payment, earnings after tax, and dividend payout ratios (dividend payment as a proportion of earnings after tax) for the U.K. companies (121 sample firms) over the period of 1974-1999 (see Appendix 1 as well).

As can be seen from these exhibits, the dividend payment of the U.K. firms was low following the imposition of dividend control during the period from 1973 to 1979. During this period, companies were permitted to increase dividends by a percentage of the previous year's dividends. The permitted percentage went from 5 percent to 12.5 percent and back to 10 percent during the period. The introduction of dividend control as part of 
Basuki-The Response of Corporate Dividend Policy to The Abolition of Tax ...

the income policy reduced the dividend payment by 20 percent (Bank of England Quarterly Bulletin, May 1987). This continued in the first half of the 1980's during the economic recession, but the dividend payment has increased significantly since 1985 .

The implementation of the dividend imputation system provides stockholders with a strong reason for preferring firms that pay dividends rather than those that retain earnings since this system eliminates the double taxation of dividends. Unlike the classical system, the imputation system provides stockholders with a credit for tax paid by the company on distributed profits. Under the imputation system, the firm passes on to the stockholders the benefit of the ACT payment in the form of an imputed tax credit. The stockholders' income is the dividends received and the tax credit. The rate of imputation has been set equal to the basic rate, so the tax credit satisfies the basic-rate tax on the shareholders' income. If the shareholders pay taxes at the basic rate, the credit eliminates the tax liability. If the shareholders' tax rate is higher than the basic rate, they will pay an additional tax liability to the Inland Revenue Service (IRS). If the shareholders are tax exempt, such as pension funds, they will receive a refund (tax credit) from the IRS.

Bond et al. (1995) claim that the imputation tax system introduces some distortions which are likely to have some effect on the level of dividend payment by the U.K. companies. Following the introduction of imputation system in 1973, many companies responded by substantially increasing their dividends. Tax-exempt investors such as pension funds are the most influential stockholders in many the

Figure 1. Dividends and Earnings After Tax of U.K. Industries

(Sample Firms) 1974-1999

\section{£ Million}

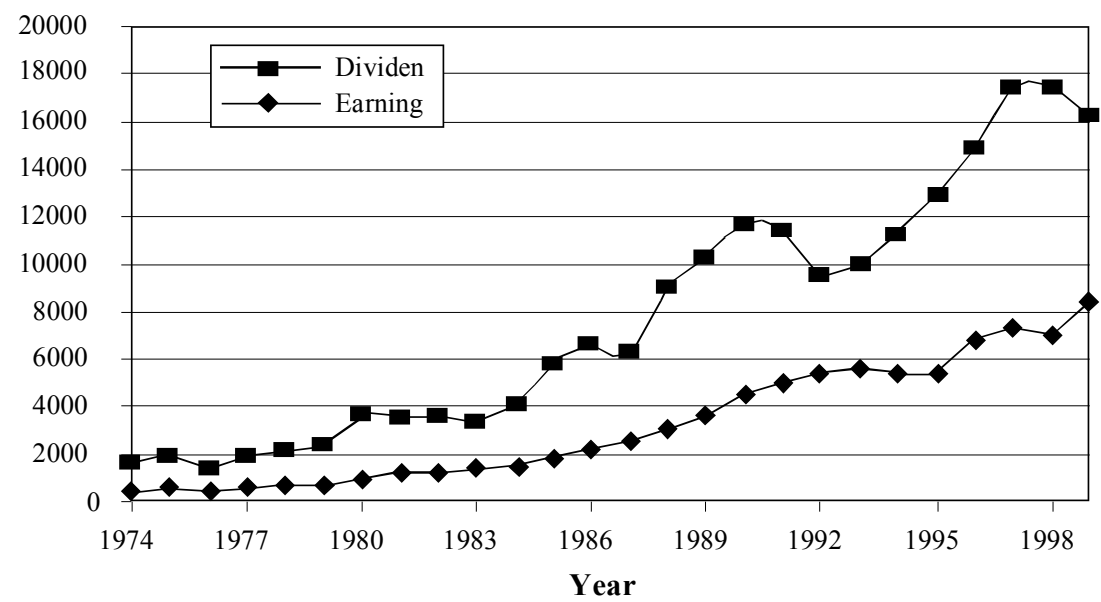


Figure 2. Dividend Payout Ratios of U.K. Industries (Simple Firms) 1974-1999

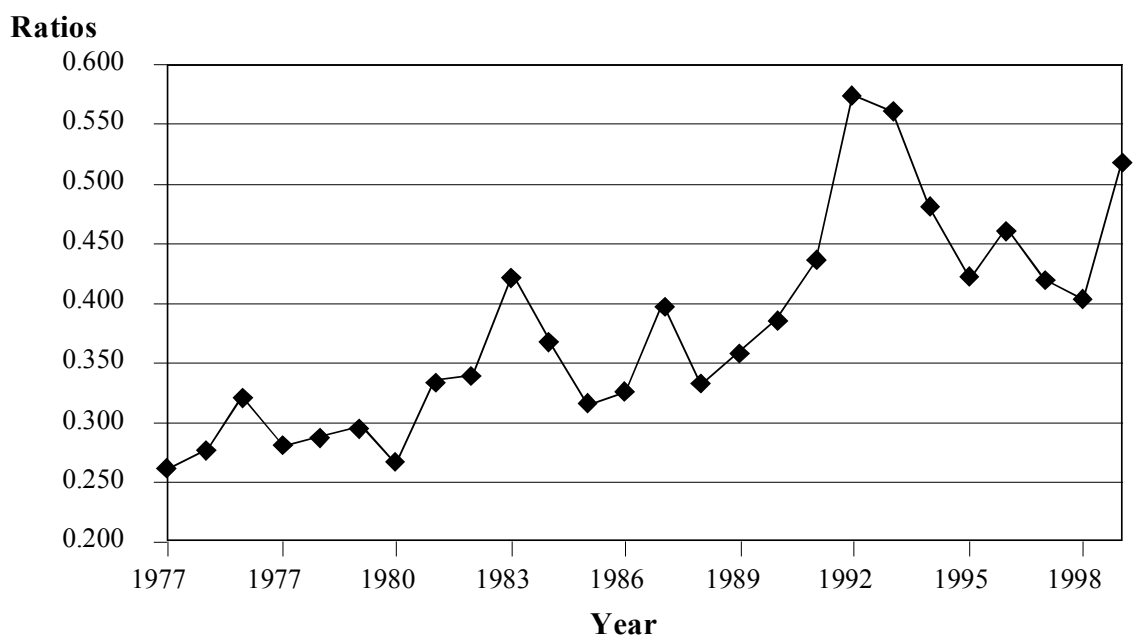

U.K. companies, and their tax preference for dividends is likely to result in high dividend payment.

Figure 1. shows an increasing pattern of dividend payment from 1974 to 1993, while earnings after tax display a more volatile pattern over the same period. The upward stickiness in the trend of the dividend behavior during that period is consistent with Lintner's (1956) findings that companies are reluctant to cut dividend payment. The volatility of earnings after tax coupled with the relative stability of dividend payment result in the erratic pattern of dividend payout ratios as shown in Figure 2 .

\section{Hypothesis Development}

The predictions of changes in investor behavior induced by changes in the tax regulation can be explained as follows. In this respect, consider the effect of the 1997 abolition of tax credit on demand for dividends. Investors realize that their returns on common shares are composed of the dividend component and the capital gains component. For example, prior to the 1997 abolition of tax credit, there was a tax preference for dividend, especially for tax-exempt investors such as pension funds since they received the tax credit facility from the U.K. government, and the effective rate for the tax-exempt shareholders was -25 percent. On the other hand, the tax rate on capital gains for the tax-exempt investors was zero.

Following the 1997 abolition of tax credit, they are no longer entitled to the payment of tax credit, and the effective rate of income tax increases to 0 percent. Therefore, the tax preference for dividends has significantly decreased. The most important taxexempt investors are pension funds since they approximately own 30 per- 
Basuki-The Response of Corporate Dividend Policy to The Abolition of Tax ...

cent of the total equity in the U.K. stock market. Thus, this group represents a significant class of investors in the U.K. market, and they may have an important impact on the dividend policy of the U.K. companies.

As a result of the abolition of tax credit on dividends, the tax advantage of dividend income declines and, ceteris paribus, the demand for high-dividendpaying stocks should decrease relative to that for low-dividend-paying stocks. Furthermore, the U.K. companies in aggregate should respond to this declined demand by reducing dividend payment. Tax-clientele theories suggest that the tax penalty on dividends suppresses the aggregate dividend payment. This study desires to examine whether corporate dividend policy is set to suit a tax clientele by looking at the effect of the 1997 abolition of tax credit on the aggregate dividend payment. This test will not be a test of the existence of tax clienteles; instead, it examines whether tax clientele serves as a major factor in determining a company's dividend policy.

If this study finds that the aggregate dividend payment decreases, it can be inferred that a company's dividend policy is set to suit a tax clientele. Thus, the hypothesis to be tested is that the 1997 abolition of tax credit on dividends results in a decrease in the aggregate dividend payment in order to satisfy a tax clientele.

\section{Methodology}

Two types of empirical tests will be conducted in this study: (1) the tests of comparison for dividend payout ratios before and after the abolition of tax credit on dividends and (2) the tests of structural shifts in the U.K. companies' dividend policies.

First, this study compares the dividend payout ratios between pre-abolition (1996-1997) and post-abolition (1998-1999) periods. Consistent with the prediction that the abolition of tax credit on dividends would decrease the tax preference for dividends, the average difference in the dividend payout ratios would be negative (dividend payout ratios of post-abolition periods would be smaller than those of preabolition period). The resulting hypothesis is:

\begin{tabular}{|c|}
$\mathrm{H}_{0}: \mu_{\mathrm{d}}=0$ \\
$\mathrm{H}_{\mathrm{a}}: \mu_{\mathrm{d}}<0$
\end{tabular}

$\mu_{d}=$ the average difference in dividend payout ratios between the two periods

This study applies one-tailed matched-pairs t-test for the sample firms. The $t$-test is calculated as follows:

$$
\mathrm{t}_{\mathrm{D}}=\frac{\mathrm{d}^{*}}{\mathrm{~s}_{\mathrm{d}} / \sqrt{\mathrm{n}}}
$$


where:

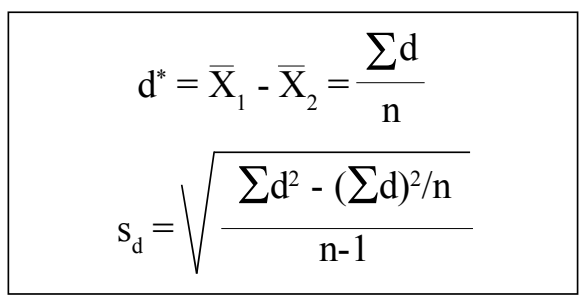

$X_{1}=$ dividend payout ratios for the post-abolition period

$X_{2}=$ dividend payout ratios for the pre-abolition period

$n$ = number of sample

The conventional significant level of 5 percent is used to test this hypothesis. Null hypothesis $\left(\mathrm{H}_{0}\right)$ is rejected if $t_{D}<-t_{\alpha, n-1}$ and thus, there is a significant difference between the pre- and post-abolition mean aggregate dividend payout ratios, and the sample firms indicate an intention to change their dividend policies following the abolition of tax credit on dividends.

The second test is to examine the structural shift in the dividend policies of the U.K. companies following the 1997 abolition of tax credit on dividends. Lintner's (1956) partial-adjustment dividend model is utilized to investigate the effect of the abolition of tax credit. Khoury and Smith (1977) employed Lintner's dividend model to examine the effect of the Canadian Tax Reform of 1972.

To forecast the expected dividend level, Lintner's approach uses the following model:

$$
D_{j, t}=\alpha_{0}+\alpha_{1} D_{j, t-1}+\alpha_{2} E_{j, t}+\varepsilon_{t}
$$

where:

$\mathrm{D}_{\mathrm{j}, \mathrm{t}}=$ the forecast dividend payment by the $j^{\text {th }}$ company in period $t$

$\mathrm{D}_{\mathrm{j}, \mathrm{t}-1}=$ the previous year's dividends

$\mathrm{E}_{\mathrm{j}, \mathrm{t}}=$ earnings after tax of $j^{\text {th }}$ company in period $t$,

$\varepsilon_{\mathrm{t}}=$ the stochastic disturbance term

To estimate the coefficients of Lintner's model for each company, this study uses the Generalized Least Square (GLS) in order to correct the serial correlation in the error terms and the lagged dependent variable. The specific technique of GLS used in this study is quasi-differencing. Normally, autocorrelation can be eliminated with a four-step technique as follows:

1. Lag the data to get $D_{t-1,} D_{t-2}$ and $E_{t-1}$ 2. Multiply the lagged values by $\rho$ (correlation coefficient between $\varepsilon_{t}$ and $\varepsilon_{t-1}$, , that is, we calculate $\rho D_{t-1}$, $\rho D_{t-2}$ and $\rho E_{t-1}$

3. Define new variables by subtracting $\rho D_{t-1}, \rho D_{t-2}$, and $\rho E_{t-1}$ from the original data: $Y_{t}^{*}=D_{t-1}-\rho D_{t-1}$; $X_{l t}^{*}=D_{t-2}-\rho D_{t-2}$, and $X_{2 t}^{*}=E_{t-1}-\rho E_{t-1}$

4. Perform ordinary least square(OLS) on the transformed data $Y_{t}^{*}=\Phi_{o}+\Phi_{1} X_{1 t}^{*}+\Phi_{2} X_{2 t}^{*}+v_{t}$

The Durbin-Watson statistic is applied to test for the serial correlation. When the ordinary least square (OLS) is performed on the transformed model, the Durbin-Watson statistic will be close to 2 . Since the $v_{t}$ is well behaved, then $\Phi_{o}, \Phi_{1}$ and $\Phi_{2}$ will be the best linear unbiased and efficient estimators (BLUE). 
Basuki-The Response of Corporate Dividend Policy to The Abolition of Tax ...

This study utilizes dividend and earnings periods of 22 years (19741995) to estimate (in time series) the partial adjustment model for each company. Once we obtain the firm-specific estimates for $\alpha_{0}, \alpha_{1}, \alpha_{2}$, we input them to forecast the estimates of for each year from 1996 to 1999.

The percentage forecasting error,

$$
\delta_{\mathrm{jt}}=\frac{\breve{\mathrm{D}}_{\mathrm{jt}}-\mathrm{D}_{\mathrm{jt}}}{\mathrm{D}_{\mathrm{jt}}}
$$

is then computed for the years of 19961999. The computed percentage forecasting error is split into pre- and postabolition of tax credit, and the following statistical hypothesis is tested.

$$
\begin{gathered}
\mathrm{H}_{0}: \mu_{1}=\mu_{2} \text {, and } \\
\mathrm{H}_{\mathrm{a}}: \mu_{1}<\mu_{2}
\end{gathered}
$$

where: $\mu_{1}=$ the sample mean of the $\delta$ for the pre-1997 abolition period

$\mu_{2}=$ the sample mean of the $\delta$ for the post-1997 abolition period
To determine whether the aggregate dividend payment changes following the 1997 abolition of tax credit, this study is applying a statistical test for the difference in means of two populations. If this test finds that the aggregate dividend payment decreases following the abolition of tax credit, then it substantiates the hypothesis that corporate dividend policy is set to suit a tax clientele.

\section{Empirical Testing and Findings}

First, this study conducts tests to compare the dividend payout ratios in the pre-abolition to those in the postabolition periods. The pre-abolition period includes a two-year period before the abolition of tax credit (1996 and 1997) while the post-abolition period includes a period of two years after the abolition (1998 and 1999). For each company, the pre- and the post-abolition dividend payout ratios are estimated as the average of the annual payout ratios in the respective period. Consistent with the prediction

\begin{tabular}{|c|c|c|c|c|c|c|}
\hline Variable & $\mathbf{N}$ & $\begin{array}{l}\% \text { Positive } \\
\text { Differences }\end{array}$ & $\begin{array}{l}\text { Mean } \\
\text { Diff. }\end{array}$ & SE Mean & t-value & p- value \\
\hline Differences* & 121 & 61.2 & 0.022 & 0.022 & 1.00 & 0.84 \\
\hline
\end{tabular}

Table 5. Matched-Pairs t-Test for the Aggregate Sample.(Dividend Payout Ratios)Test of $\mathrm{Ho}: \mu=0$ vs Ha: $\mu<0$ 
Gadjah Mada International Journal of Business, May - August 2007, Vol. 9, No. 2

that the abolition of tax credit on dividends would decrease the tax preference for dividends, this study applies one-tailed matched-pairs t-test to the sample of the U.K. companies. This research tests the null hypothesis that the mean of the pair-wise differences over the two periods is equal to zero, and the alternative hypothesis that this mean is smaller than zero. The conventional significant level of 5 percent is used to test this hypothesis. Table 5 presents the results of the matchedpairs t-test for the aggregate sample.

The percentage of positive differences in dividend payout ratios in Table 5 shows that 61.2 percent of the companies experienced increases in their dividend payout ratios following the 1997 abolition of tax credit on dividends. However, the statistical results show that the null hypothesis of zero average difference cannot be rejected at the 5 percent significance level (onetailed test). Hence, there is no significant difference between the pre- and the post-abolition mean aggregate dividend payout ratios, and the sample firms indicated no intention to change their dividend policies in response to the abolition of tax credit on dividends.

It is possible that these tests in the aggregate sample cannot reveal significant changes in dividend payout ratios for different groups of shares. Prior evidence regarding the existence of investor tax clienteles across the dividend yield spectrum suggests the possibility that a change in tax rate on dividends could not change investor preferences with regard to dividends and capital gains. Robin (1991) conducted a study concerning the impact of the 1986 Tax Reform Act (this act equalized the marginal tax rates of capital gains and dividend income) on ex-dividend day returns in the U.S. market. He finds a greater impact of the 1986 Tax Reform Act (TRA) on the high-dividend-yield group than on the lower-dividend-yield group. This observation probably contains the impact of dividends captured by Japanese investors. It is also possible that companies with high dividend payout ratios in the pre-1986 TRA period would be reluctant to increase their dividend payment since the higher dividend payout could not be sustained in the long-term period.

Consequently, this study classifies the sample companies into five groups according to their pre-abolition dividend payout ratios as follows:

Group 1: Dividend Payout Ratios from 0.01 to 0.30 (10 companies)

Group 2: Dividend Payout Ratios from 0.301 to 0.40 (36 companies)

Group 3: Dividend Payout Ratios from 0.401 to 0.50 (33 companies)

Group 4: Dividend Payout Ratios from 0.501 to 0.60 (25 companies)

Group 5: Dividend Payout Ratios greater than 0.601 (17 companies) 
Basuki-The Response of Corporate Dividend Policy to The Abolition of Tax ...

Table 6. Matched-pairs t-tests for 5 Groups of Sample Firms (Dividend Payout Ratios)

Ho $: \mu_{D}=0$ vs Ha: $\mu_{D}<0$

\begin{tabular}{|c|c|c|c|c|c|c|c|c|}
\hline Group & $\mathbf{N}$ & $\begin{array}{l}\text { \% Positive } \\
\text { Difference }\end{array}$ & $\begin{array}{c}\text { Mean } \\
\text { Payout } \\
\text { Pre- } \\
\text { Abolition }\end{array}$ & $\begin{array}{c}\text { Mean } \\
\text { Payout } \\
\text { Post- } \\
\text { Abolition }\end{array}$ & $\begin{array}{c}\text { Mean } \\
\text { Diff. }\end{array}$ & $\begin{array}{c}\text { SE Mean } \\
\text { Diff. }\end{array}$ & $\begin{array}{c}\mathrm{t}- \\
\text { value }\end{array}$ & $\begin{array}{c}\mathrm{p}- \\
\text { value }\end{array}$ \\
\hline 1 & 10 & $80.00 \%$ & 0.2035 & 0.2900 & 0.0865 & 0.0627 & 1.38 & 0.90 \\
\hline 2 & 36 & $75.00 \%$ & 0.3621 & 0.4214 & 0.0593 & 0.0177 & 3.35 & 1.00 \\
\hline 3 & 33 & $72.70 \%$ & 0.4491 & 0.5221 & 0.0730 & 0.0254 & 2.87 & 1.00 \\
\hline 4 & 25 & $56.00 \%$ & 0.5430 & 0.5969 & 0.0539 & 0.0489 & 1.10 & 0.86 \\
\hline 5 & 17 & $11.80 \%$ & 0.7960 & 0.5570 & -0.2390 & 0.1030 & -2.32 & 0.017 \\
\hline
\end{tabular}

Subsequently, the matched-pairs t-test for each group is repeated. The statistical results reported in Table 6 reveal a slight difference from the test results using the aggregate sample in Table 5.

The mean differences of dividend payout ratios for the four groups are positive; 0.0865 (Group1), 0.0593 (Group 2), 0.0730 (Group 3), and 0.0539 (Group 4). The mean dividend payout ratios for these groups increased, respectively, from 0.2035 , $0.3621,0.4491$, and 0.5430 in the preabolition period to $0.2900,0.4214$, 0.5221 , and 0.5969 in the post-abolition period. However, the statistical findings show that the null hypothesis of zero average difference cannot be rejected at five percent significance level (one-tailed test). Thus, there is no significant difference between the preand post-abolition periods. These findings are similar to the evidence presented by Bolster and Janjigian (1991) who examined changes in dividend policies of the U.S. companies following the enactment of 1986 Tax Reform Act. They also find that dividend payout ratios do not change after the passage of the tax reform.

The majority of the U.K. firms indicate no intention to reduce their dividend payment in response to the abolition of tax credit on dividends. It is possible that companies with low to medium payout ratios in the pre-abolition period would be reluctant to cut their dividend payment since this dividend payout could be sustained in the long run.

Table 6 shows that only a minority of the U.K. companies (Group 5: highest payout ratios) experienced decreases in their dividend payout ratios, the mean payout ratios decreased from 0.7960 to 0.5570 between the pre- and the post-abolition periods. For companies in Group 5, the null hypothesis of zero mean of the difference in the pre- 
and post-abolition periods can be rejected at 5 percent confidence level. Therefore, Group 5 shows a statistically significant decrease in the dividend payout ratios. Most of the companies in Group 5 (88.2\%) experienced a payout decrease whereas only 11.8 percent had a payout ratio increase. Since tax-exempt investors, such as pension funds, are the principle clientele for high-dividend-payout shares, this finding is consistent with the reduction in the relative tax advantage of dividend income over capital gains for these investors as a result of the 1997 abolition of tax credit on dividends.

After 1997, most companies in Group 5 have adjusted their dividend payout ratios in accordance with the prediction of tax-based dividend behavior model. The effective rate for the tax-exempt investors was -25 percent, but after the 1997 abolition of tax credit, they are no longer entitled to the payment of tax credit, and the effective rate of income tax increases to 0 percent. This new tax rate reduces the relative preference for dividend payment of investors whose dividend income is taxable at zero rate. Thus, the demand for high-dividend-paying shares should decrease relative to lowdividend-paying shares, and companies should respond to this declined demand by reducing dividend payout.

The second test is conducted in this study to gain further evidence of the effect of the abolition of tax credit. Lintner's (1956) partial-adjustment dividend model is used to investigate the structural shift in the dividend policies of the U.K. companies following the 1997 abolition of tax credit on dividends. This model is a valid empirical representation of the intertemporal behavior of dividend payment as shown by Fama and Babiak (1968). They find that Lintner's model performs well. Khoury and Smith (1977) utilized Lintner's (1956) model to observe how the dividend policies of Canadian companies were affected by a change in tax structure.

Lintner's model, which forecasts current dividend level as a function of past dividend payment and current earnings, may provide an estimate of normal expected dividends.

The empirical specification of Lintner's model to forecast expected dividend level is:

$$
D_{t}=\alpha_{0}+\alpha_{1} D_{t-1}+\alpha_{2} E_{t}+u_{t}
$$

where $D_{t}=$ the forecasted dividend payment in period $t$,

$\mathrm{D}_{\mathrm{t}-1}=$ the previous year's dividends,

$\mathrm{E}_{\mathrm{t}}=$ earnings after tax in pe$\operatorname{riod} t$,

$\mathrm{u}_{\mathrm{t}}=$ the stochastic disturbance term.

This study utilizes dividend and earnings periods of 22 years (19741995) to estimate (in time series) to generate Lintner's model's coefficients. After the estimates of $\alpha_{0}, \alpha_{1} \alpha_{2}$ are obtained, this study uses them to forecast the estimate of $\breve{\mathrm{D}}$ (expected 
Basuki-The Response of Corporate Dividend Policy to The Abolition of Tax ...

dividends) for each of the years 19961999. Subsequently, the percentage of forecasting error,

$$
\delta_{\mathrm{jt}}=\frac{\breve{\mathrm{D}}_{\mathrm{jt}}-\mathrm{D}_{\mathrm{jt}}}{\mathrm{D}_{\mathrm{jt}}}
$$

is computed for the years 1996-1999. If the actual dividend payment $\left(D_{j t}\right)$ is zero while the expected dividends $\left(\breve{\mathrm{D}}_{\mathrm{jt}}\right)$ is not zero, then the company is excluded from the sample.

This study uses aggregate data as well as individual company data to test the structural shift in dividend payment. In each year, the aggregate dividends and earnings are calculated by summing, respectively, the company's total dividends and earnings. As already mentioned, 121 companies are derived from 20 industry groups (sectors); each sector has at least two companies.

Table 7 shows the percentage of forecast error $\left(\delta_{t}\right)$ for 20 sectors in the U.K. industries. A positive number indicates that dividend payment is lower than expected. In other words,

Table 7. Percentage of Forecast Error $\left(\delta_{\mathrm{j} t}\right)$

\begin{tabular}{|c|c|c|c|c|}
\hline Sector & 1996 & 1997 & 1998 & 1999 \\
\hline 1.Med Equip \& Supplies & -0.039 & -0.030 & -0.092 & -0.135 \\
\hline 2. Auto Parts & -0.030 & 0.061 & -0.010 & 0.079 \\
\hline 3. Building Materials & 0.035 & -0.116 & 2.031 & 0.111 \\
\hline 4. Restaurant, Hotel, Pubs & -0.058 & -0.033 & 0.002 & 0.353 \\
\hline 5. Chemicals & 0.034 & -0.042 & -0.045 & -0.012 \\
\hline 6. Electronic & -0.125 & -0.019 & -0.062 & 0.137 \\
\hline 7 Telecom & -0.018 & 0.009 & -0.044 & 0.050 \\
\hline 8. Food \& Drug Retailers & 0.060 & -0.061 & 0.093 & 0.090 \\
\hline 9. Publishing \& Printing & -0.199 & 0.029 & -0.021 & -0.009 \\
\hline 10.Business Support & 0.109 & 0.081 & 0.059 & 0.098 \\
\hline 11.Distributor & -0.040 & 0.018 & -0.280 & -0.098 \\
\hline 12.House Building & -0.099 & 0.042 & 0.031 & 0.110 \\
\hline 13.Food Processors & 0.027 & -0.054 & 0.071 & -0.058 \\
\hline 14.Transports & -0.119 & 0.034 & 0.330 & 0.297 \\
\hline 15.Retailers & -0.375 & 0.070 & -0.063 & -0.336 \\
\hline 16.Defence \& Aerospace & -0.021 & -0.003 & 0.015 & 0.149 \\
\hline 17.Distiiler \& Vintners & -0.318 & 0.227 & 0.511 & -0.651 \\
\hline 18.Engineering & -0.030 & 0.001 & -0.025 & -0.025 \\
\hline 19.Oil \& Other Mining & -0.050 & -0.041 & 0.243 & -0.518 \\
\hline 20. Other Constructions & -0.059 & -0.047 & -0.131 & 0.110 \\
\hline Average Forecast Errors & -0.066 & 0.006 & 0.131 & -0.013 \\
\hline
\end{tabular}


Gadjah Mada International Journal of Business, May - August 2007, Vol. 9, No. 2

Table 8. Two-Sample t-Test

Forecast Errors Pre-Abolition vs. Post-Abolition Periods

\begin{tabular}{|c|c|c|c|c|}
\hline & $\mathbf{N}$ & Mean & Std. Dev & SE Mean \\
\hline Pre-Abolition & 20 Sectors & 0.009 & 0.167 & 0.037 \\
\hline Post-Abolition & 20 Sectors & 0.098 & 0.295 & 0.066 \\
\hline \multicolumn{5}{|c|}{$\begin{array}{c}\text { 95\% CI for } \mu \text { Pre-Abolition }-\mu \text { Post-Abolition : }(-0.243,0.066) \\
\text { T-Test } \mu \text { Pre-Abolition }=\mu \text { Post-Abolition }(\mathrm{vs}<): \mathrm{T}=-1.17 \mathrm{P}=0.13 \mathrm{DF}=30\end{array}$} \\
\hline
\end{tabular}

dividend forecasts $\left(\breve{\mathrm{D}}_{\mathrm{jt}}\right)$ using Lintner's model are higher than actual dividends $\left(D_{\mathrm{j} t}\right)$. Meanwhile, a negative value of forecast error indicates that dividend forecast is lower than actual dividends $\left(\breve{D}_{\mathrm{jt}}<\mathrm{D}_{\mathrm{jt}}\right)$. Table 7 reveals that the average values of forecast errors for the years 1996-1999 are negative, indicating upward shifts in dividend payment. The positive value in 1998 apparently represents the evidence of a downward shift as a result of the taxcredit abolition.

To investigate whether the aggregate dividend payment changed following the 1997 abolition of tax credit, a statistical test of the difference in means of two populations was applied. Table 8 presents the results of twosample $t$-test for pre- and post-abolition periods. It can be observed from Table 8 that the percentage of forecast error in Lintner's model did not change between pre- and post-abolition periods. In other words, the aggregate dividend payment did not decrease following the abolition of tax credit.

The resulting $\mathrm{p}$-value is $p=0.13$ and since this value is greater than the significance level of 0.05 , we cannot reject the null hypothesis $\left(\mu_{1}=\mu_{2}\right)$.
Thus, this test fails to provide a support for the hypothesis that corporate dividend policy is set in response to a tax clientele.

As already mentioned, the sample firms are classified into five groups according to their pre-abolition dividend payout ratios. Subsequently, this study repeats the two-sample t-tests for each group, and the statistical results are reported in Table 9. These results are slightly different from the test results using the aggregate sample in Table 8. As can be seen from Table 10 , the resulting $\mathrm{p}$-value for 4 groups are $p=0.50$ (Group 1 ), $p=0.078$ (Group 2), $p=0.79$ (Group 3), and $p=0.25$ (Group 4). Thus, the null hypothesis that dividend policy remains unchanged following the abolition of tax credit cannot be rejected at the 5 percent significance level (one-tailed test), or there is no significant difference between the pre- and post-abolition periods. Table 9 shows only companies in Group 5 (the highest payout ratio); it has a $\mathrm{p}$-value of $(\mathrm{p}=0.032)$, less than $a=0.05$. Thus, the null hypothesis of a zero mean of the difference in the pre- and post-abolition periods can be rejected at five-percent 
Basuki-The Response of Corporate Dividend Policy to The Abolition of Tax ...

Table 9. Two-Sample t-Test per Group Forecast Errors Pre-Abolition vs Post-Abolition Periods $\left(\mathrm{H}_{0}=\mathbf{0}\right.$ vs $\left.\mathrm{H}_{\mathrm{a}}<0\right)$

\begin{tabular}{|c|c|c|c|c|}
\hline GROUP 1 & $\mathbf{N}$ & Mean & StDev & SE Mean \\
\hline Pre-Abolition & 10 & 0.249 & 0.799 & 0.25 \\
\hline Post-Abolition & 10 & 0.246 & 0.713 & 0.23 \\
\hline
\end{tabular}

95\% CI for $\mu$ Pre-Abolition - $\mu$ Post-Abolition: $(-0.71,0.72)$

T-Test $\mu$ Pre-Abolition $=\mu$ Post-Abolition (vs $<$ ): $\mathrm{T}=0.01 \mathrm{P}=0.50 \mathrm{DF}=17$

\begin{tabular}{|c|c|c|c|c|}
\hline GROUP 2 & $\mathbf{N}$ & Mean & StDev & SE Mean \\
\hline Pre-Abolition & 36 & -0.059 & 0.223 & 0.037 \\
\hline Post-Abolition & 36 & 0.035 & 0.325 & 0.054 \\
\hline
\end{tabular}

95\% CI for $\mu$ Pre-Abolition - $\mu$ Post-Abolition : $(-0.226,0.037)$

T-Test $\mu$ Pre-Abolition $=\mu$ Post-Abolition $(\mathrm{vs}<)$ : $\mathrm{T}=-1.44 \mathrm{P}=0.078 \mathrm{DF}=61$

\begin{tabular}{|c|c|c|c|c|}
\hline GROUP 3 & $\mathbf{N}$ & Mean & StDev & SE Mean \\
\hline Pre-Abolition & 33 & 0.015 & 0.192 & 0.033 \\
\hline Post-Abolition & 33 & -0.017 & 0.103 & 0.018 \\
\hline
\end{tabular}

95\% CI for $\mu$ Pre-Abolition - $\mu$ Post-Abolition E: ( $-0.045,0.108)$

T-Test $\mu$ Pre-Abolition $=\mu$ Post-Abolition (vs $<$ ): $\mathrm{T}=0.82 \mathrm{P}=0.79 \mathrm{DF}=49$

\begin{tabular}{|c|c|c|c|c|}
\hline GROUP 4 & $\mathbf{N}$ & Mean & StDev & SE Mean \\
\hline Pre-Abolition & 25 & 0.024 & 0.133 & 0.027 \\
\hline Post-Abolition & 25 & 0.140 & 0.831 & 0.17 \\
\hline
\end{tabular}

95\% CI for $\mu$ Pre-Abolition - $\mu$ Post-Abolition: $(-0.462,0.23)$

T-Test $\mu$ Pre-Abolition $=\mu$ Post-Abolition (vs $<$ ): $\mathrm{T}=-0.69 \mathrm{P}=0.25 \mathrm{DF}=25$

\begin{tabular}{|c|c|c|c|c|}
\hline GROUP 5 & $\mathbf{N}$ & Mean & StDev & SE Mean \\
\hline Pre-Abolition & 17 & -0.026 & 0.178 & 0.043 \\
\hline Post-Abolition & 17 & 0.335 & 0.73 & 0.18 \\
\hline
\end{tabular}

95\% CI for $\mu$ Pre-Abolition - $\mu$ Post-Abolition: $(-0.746,0.02)$

T-Test $\mu$ Pre-Abolition $=\mu$ Post-Abolition (vs $<$ ): $\mathrm{T}=-1.98 \mathrm{P}=0.032 \mathrm{DF}=17$ 
confidence level. This finding is consistent with the results in Table 7 where Group 5 shows a statistically significant decrease in the dividend policy. This evidence supports the hypothesis that the 1997 abolition of tax credit on dividends results in the decrease in aggregate dividend payment in order to satisfy a tax clientele.

\section{Summary and Conclusions}

This study investigates whether the U.K. corporate dividend policy responds to the 1997 abolition of tax credit on dividends. Following the 1997 abolition of tax credit on dividends, tax-exempt investors are no longer entitled to the payment of tax credit. The effective rate of income for taxexempt investors such as pension funds increases from minus -25 percent to 0 percent, and thus the tax preference for dividends has significantly decreased. Pension funds approximately own 30 percent of the total equity in the U.K. stock market. Hence, this group is the most influential stockholders in many the U.K. companies, and their tax preference for dividends may have an important impact on corporate dividend policy.

The hypothesis regarding the dividend behavior of the U.K. companies in response to the tax regulation is formulated and tested. First, this study examines the hypothesis that the 1997 abolition of tax credit on dividends results in a decrease in dividend payout ratios. The findings of the study are mostly not supportive of this hypoth- esis. In particular, we find that the majority of the sample companies (Group 1, 2, 3, and 4) do not change their dividend policies after the abolition of tax credit. On the contrary, companies in Group 5 with the highest payout ratios decrease their dividend payout ratios. This finding is consistent with the view that companies respond to the realignment of the tax rate on capital gains and dividends by conducting appropriate adjustment to dividend payout ratios.

This study also conducts tests to investigate whether the aggregate dividend payment changes following the 1997 abolition of tax credit. This study finds that the percentage of forecast error in Lintner's model does not change between pre- and post-abolition periods In other words, the aggregate dividend payment does not decrease following the abolition of tax credit.

Overall, the findings of this study provide evidence that the majority of the sample companies do not change their dividend policy in accordance with the tax-based predictions following the 1997 abolition of tax credit on dividends. For such companies, other factors such as information release and signaling may have greater impacts on their dividend policies. Only the minority of the sample experience a decline in their dividend payment. This evidence supports the hypothesis that the abolition of tax credit on dividends results in a decrease in aggregate dividend payment in order to satisfy a tax clientele. 
Basuki-The Response of Corporate Dividend Policy to The Abolition of Tax ...

Obviously, this study has some limitations. Even though the sample is representative, the sample size is not large. Furthermore, since the study uses two years of experiences after the 1997 abolition of tax credit on dividends and only annual data available, these may reduce the strength of any findings from this study.

\section{References}

Ashton, D. J. 1991. Corporate financial policy: American analytics and U.K. taxation. Journal of Business Finance and Accounting 18 (4): 465-482.

Asquith, P., and D. W. Mullins. 1983. The impact of initiating dividend payments on shareholders' wealth. Journal of Business 56 (1): 77 - 96.

Baker, H. K., G. E. Farrelly, and R. B. Edelman. 1985. A survey of management views on dividend policy. Financial Managment: 78-84.

Bank of England. 1987. Companies' long-term financial decision; dividends and Debt. Bank of England Quarterly Bulletin (May): 261.

Beales, G. 1998. 1998-1999 Income Tax and NIC for the Self-employed Handbook. Surrey: Croner Publication Ltd.

Benartzi S, R. Michaely., and R Thaler. 1997. Do changes in dividends signal the future or the Past? Journal of Finance: 1007-1034.

Benito, A., and G. Young. 2003. Hard times or great expectations? Dividend omissions and dividend cuts by U.K. Firms. Oxford Bulletin of Economics and Statistics 65 (5): 531-555.

Bolster,P. J., and V. Janjigian. 1991. Dividend policy and valuation effects of the Tax Reform Act of 1986. National Tax Journal (December): 511-518.

Bond, S., L. Chennels, and M. Devereux. 1995. Company dividends and taxes in the UK. Fiscal Studies 16 (3).

Brenan, M. J. 1970. Taxes, market valuation and corporate financial policy. National Tax Journal 23: 417.

Brigham, E. J., and L. C. Gapenski. 1987. Intermediate Financial Management ( $\left.2^{\text {nd }} e d.\right)$. The Dryden Press.

Brown, G. 1997. Budget statement. HANSARD-Parliamentary Debate, House of Commons Official Report 297 (33): 306.

Butterworths. 1997. Simon's Direct Tax Service: Budget Bulletin 1997. Scotland: Thomson Litho Ltd.

Central Statistical Office. 1994. Annual supplement 1994 edition. Economic Trends: 100.

Chui, A., N. Strong, and J. Cadle. 1992. The empirical significance of tax effects on the valuation of dividends: The U.K. evidence. Journal of Business Finance and Accounting 19 (4): 515-532. 
Gadjah Mada International Journal of Business, May - August 2007, Vol. 9, No. 2

Dyl , E. A., and J. R. Hoffmeister. 1986. A note on dividend policy and beta. Journal of Business Finance and Accounting 13 (1): 107-115.

Easterbrook, F. H. 1984. Two agency-cost explanations of dividends. The American Economic Review LXXIV (4): 650.

Elton, E. J., and M. J. Gruber. 1970. Marginal stockholder tax rates and the clientele effect. The Review of Economics and Statistics LII (1): 68-74.

Fama, E. F., and H. Babiak. 1968. Dividend policy: An empirical analysis. The Journal of the American Statistical Association 63: 1132-1161.

Farrar, D. and L. Selwyn. 1967. Taxes, corporate financial policy and return to investors. National Tax Journal: 444-454.

Feldstein, M. S. 1970. Corporate taxation and dividend behaviour. Review of Economic Studies 37: 57-72

Foreman, A. 1998. Tax Handbook 1998-1999. London: Allied Dunbar Assurance plc.

Hakansson, N. H. 1982. To pay or not to pay dividend. Journal of Finance XXXVII (2): 415.

Jensen, M.C (1986), Agency cost of free cash flow, corporate finance and takeovers, The American Economic Review 76 (2): 323-329.

Kay, J. A and M. A. King. 1990. The British Tax System (5 $5^{\text {th }}$ ed.). Oxford: Oxford University Press.

Khoury N. T., and K. V. Smith. 1977. Dividend policy and capital gain tax in Canada. Journal of Business Administration 8: 19-37.

Lakonishok, J., and T. Vermaelen. 1983. Tax reform and ex-dividend day behaviour. Journal of Finance XXXVIII (4): 1157.

Lasfer, M. A. 1995. Ex-day behaviour: Tax or short-term trading effects. Journal of Finance L (3): 875 - 897.

Lasfer, M. A. 1996. Taxes and dividends: The UK evidence. Journal of Banking and Finance 20: 455.

Lintner, J. 1956. Distribution of incomes of corporations among dividends, retained earnings, and taxes. American Economic Review (46).

Litzenberger, R. H., and K. Ramaswamy. 1982. The effect of dividend on common stock prices: Tax effect or information effect. Journal of Finance XXXVII: 429.

Miller, M. H., and K. Rock. 1985. Dividend policy under asymmetric information. Journal of Finance 40: 1031

Miller, M. H., and F. Modigliani. 1961. Dividend policy, growth, and the valuation of shares. Journal of Business XXXIV (4): 411-433.

Nissim, D. and A. Ziv. 2001. Dividend changes and future profitability. The Journal of Finance LVL (6): 2111-2133.

Papaioannou, G. J., and C. M. Savarese. 1994. Corporate dividend policy response to the Tax Reform Act of 1986. Journal of The Financial Management Association. 23 (1): 56-65. 
Basuki-The Response of Corporate Dividend Policy to The Abolition of Tax ...

Penman, S. H. 1983. The predictive content of earnings forecasts and dividends. Journal of Finance XXXVIII (4): 1181-1199

Pettit, R. R. 1972. Dividend announcements, security performance, and capital market efficiency. Journal of Finance XXVII (5).

Pettit R. R. 1977. Taxes, transaction cost and clientele effect of dividend. Journal of Financial Economics: 419.

Poterba, J., and L. H. Summer. 1984. New evidence that taxes affect the valuation of Dividends. Journal of Finance: 1397-1415

Poterba, J. M. 1987. Tax policy and corporate saving. Brookings Papers on Economic Activity (2): 455-503.

Ridgway, P. 1997. Imputation system - born 1973; died 3 July 1997 RIP? Taxation 139 (3614): 390.

Robin, A. J. 1991. The impact of the 1986 tax reform act on ex-dividend day returns. Journal of Financial Management Association 20 (1): 60-70.

Ryan, T. M. 1974. Dividend policy and market valuation in British industry. Journal of Business Finance and Accounting 1 (3): 415-428.

Shefrin, H. M., and M. Statman. 1984. Explaining investor preference for cash dividend. Journal of Financial Economics 13 (2): 253-282.

Theobald, M. 1978. Intertemporal dividend models: An empirical analysis using recent U.K. data. Journal of Business Finance and Accounting: 123-135.

Tingley, K. R. 1999. Income Tax Guide 1999-2000. Daily Mail, Orion Business Book.

Van Horne, J. C. 1983. Financial Management and Policy (6 ${ }^{\text {th }}$ ed.). Englewood Cliffs, NJ: Prentice Hall.

Watts, R. 1973. The information content of dividends. Journal of Business 46: 191-211.

Woolridge, J. R. 1983. Dividend changes and security prices. Journal of Finance XXXVIII (5): 1607 - 1615.

Zodrow, G. R. 1991. On the traditional and new views of dividend taxation. National Tax Journal XLIV: 497-509. 